\title{
A STRATÉGIAI MENEDZSMENT NEMZETKÖZI FEJLŐDÉSE AZ UTÓBBI NEGYEDSZÁZADBAN - ELMÉLETI ÁRAMLATOK ÉS TUDOMÁNYÁGI PERSPEKTIVÁK
}

\author{
LAST 25 YEARS OF THE STRATEGIC MANAGEMENT'S \\ INTERNATIONAL EVOLUTION - \\ THEORETICAL TENDENCIES AND SCIENCE PERSPECTIVES
}

\begin{abstract}
A legutóbbi 25 évet átfogó elemzés a korábban kibontakozott két stratégiaelméleti irányzat mentén követi a tudományág újabb fejlődését. Az egyik irányzat képviselői racionális-normatív folyamatnak tekintették a vállalati stratégiaalkotást. $A$ vizsgált időszakban még hatnak a racionális-normatív megközelítés versenyelőny koncepciói (iparág-szerkezeti és erőforrás-alapú nézőpontok). Ugyanakkor előtérbe került a tulajdonosiérték-szemlélet, továbbá megerősödtek a társadalmilag felelős vállalatra vonatkozó elvárások. A másik stratégiaelméleti irányzat követői leíró-magyarázó módon közelítették meg a stratégiát: a stratégiaalkotást szervezeti folyamatként (például tanulási, megismerési, tárgyalási-alkudozási vagy passzív alkalmazkodási formálódásként) értelmezték. Ehhez a felfogáshoz új áramlatok kapcsolódtak a stratégia magatartástudományi megközelítésével, valamint a stratégiai entrepreneurship elgondolásával. Egyidejűleg felértékelődött az intézmények szerepe a stratégiai teljesítmény megítélésében, továbbá megjelent a stratégiai menedzsment praxeológiai magyarázata. A fejlődéstörténeti áttekintés végül választ keres az időszerű kérdésre: túlhaladott-e a tudományterület a 2008-2009. évi világválság stratégiaalkotási tanulságainak tükrében?
\end{abstract}

Kulcsszavak: racionális és spontán stratégiaalkotás, öttényezős modell, szervezeti erőforrás, tulajdonosi vállalatérték, felelős társaságirányítás, magatartási stratégia, stratégiai vállalkozáselmélet, intézményalapú nézőpont, stratégia mint gyakorlat.

The historical analysis of the starategic management embraces the last 25 years of science evolution, following along two principal tendencies (prescriptive-rational and descriptive-interpretative) of strategy formulation concept. In this period the industry structure-based view and resource-based view of prescriptive-rational tendency still influence the stategic management theory. At the same time such approaches like shareholder value, steakholder value and corporate social responsibility forged ahead step by step. The descriptive-interpretative tendency considers strategy formulation as a cognitive, learning, negotiating-bargaining or passive adapting process. New streams of the descriptive-interpretative tendency emerged from the turn of the millenium: for example behavioral strategy, institution-based view, strategic entrepreneurship, strategy-as-practice. Concluding the historical survey, this study looks for an answer concerning the question of the future of the strategic management discipline.

Key words: rational and spontaneaus formulation of strategy, five forces model, resource-based view. shareholder and steakholder values, corporate governance, behavioral and entrepreneurial strategies, institution-based view, strategy-aspractice

\section{Finanszírozás/Funding:}

A szerző a tanulmány elkészítésével összefüggésben nem részesült pályázati vagy intézményi támogatásban. The author did not receive any grant or institutional support in relation with the preparation of the study.

\section{Szerző/Author:}

Dr. Tari Ernő, professor emeritus, Budapesti Corvinus Egyetem, (erno.tari@uni-corvinus.hu)

A cikk beérkezett: 2019.05.23-án, javítva: 2019.08.18-án, elfogadva: 2019.10.20-án.

This article was received: 23.05.2019, revised: 18.08.2019, accepted: 20.10.2019. 
A stratégiai menedzsment mint önálló tudományterület több évtizedes múltra tekinthet vissza. A tudományág irodalma óriási, mondhatni határtalan; az ismeretanyag szakkönyvek és szakfolyóiratok sokasága révén, valamint digitális formában jut el az érdeklődő olvasókhoz. A témakört valamilyen változatban szinte minden felsőfokú közgazdasági és menedzsmentoktatási intézményben tanítják, külföldön és hazánkban egyaránt.

Hosszabb kutatási és oktatási tapasztalat birtokában kíséreljük meg a diszciplína fejlődéstörténetének összefoglaló bemutatását, hangsúlyosan az utolsó negyedszázad áttekintésével. Kutatási módszerünk a szakirodalom feldolgozása volt. A stratégiai menedzsment kifejlődő két alapvető elméleti irányzatának (a racionális-normatív és a leíró-magyarázó megközelítéseknek) pontos keresztmetszetét adta közre az 1990-es évtized vége felé a kanadai McGill Egyetem kutatócsoportja (Mintzberg et al., 1998). Jelen írásunkban a két irányzat párhuzamos tovább fejlődésének körvonalazására vállalkozunk, az azóta eltelt időszak legfontosabb elméleti munkáinak feldolgozásával.

A tanulmány befejező része voltaképp latolgatás az elméleti áramlatok fejlődésének tükrében: Milyen válaszokat képes adni a stratégiai menedzsment a jelenkor gazdasági-társadalmi kihívásaira? Miként tükröződnek a környezet radikális változásai a tudományág újabb evolutív szakaszában? Avagy túlhaladott a stratégia eszmei rendszere (és módszertani eszköztára), s iránymutató funkcióját átadni kényszerül egy más jellegű vezetési felfogásnak, filozófiának?

\section{Előzmények: a stratégiai menedzsment két alapvető irányzatának kialakulása és fejlődése az 1990-es évekig}

\section{A stratégiaalkotás mint racionális folyamat}

A vállalati stratégiaalkotás elméleti igényességü tárgyalása az 1960-as évtizedtől jelent meg a menedzsmentirodalomban. A stratégiaelmélet úttöröi, a Harvard Business Schoool tanárai dolgozták ki a vállalati stratégiát megalapozó külső és belső diagnózis első modelljét, amely SWOT-elemzés néven vonult be a stratégiai gondolkodás történetébe (Learned et al., 1965). A Harvard-iskola tagjai olyan fogalmi apparátust (környezetelemzés, szervezeti belső analízis, megkülönböztető képességek, sikertényezők, stratégiai illeszkedés) használtak, amelynek összetevőit a későbbiekben szinte minden stratégiai elemzési modellben alkalmazták.

A korai stratégiaelmélet talán legnagyobb hatású müve Ansoff (1965) nevéhez füződik. Könyvében - amely tíznél több kiadást ért meg az Egyesült Államokban - elvi különbséget tett a cégstratégia eltérő szintjei között. Felismerte, hogy más és más jellegű távlati kérdések merülnek fel a vállalat egészének perspektívájából, az egyes üzletágak (üzleti egységek) szintjén, valamint a funkcionális területek (részlegek) nézőpontjából. Ansoff érdeme továbbá, hogy megalkotta azt a stratégiai tervezési folyamatmodellt (process-based view), amely rokonságot mutatott a Harvard-iskola stratégiaalkotási (design) felfogásával és hasznosította a hosszabb távú tervezés korábbi vállalati tapasztalatait.
A stratégiai elmélet (és módszertan) az 1970-es évtized során a vállalati stratégiai pozíció elemzésében lépett a legnagyobbat elöre. Három ismert amerikai vezetési tanácsadó cég (BCG, McKinsey, ADL) új szakaszt nyitott a stratégiát megalapozó portfólióanalízisek kimunkálásával (product/market view). A portfóliómodellek - minden korlátozottságuk ellenére - hasznos, könnyen kezelhetö elemzési eszköznek bizonyultak a stratégiai tervezésben; gyakorlati alkalmazásukkal lehetővé vált - különösen a nagyvállalatok körében - a befektetések sorrendiségének, az erőforrások súlypontjainak megalapozottabb kijelölése.

További elörelépésnek volt tekinthető a stratégiai menedzsment fejlödéstörténetében a vállalati misszió (küldetés) és a vízió (jövőkép) fogalmainak tisztázása. A küldetés explicit megfogalmazását Pearce és David (1987) azért tartották stratégiailag fontosnak, mert - érvelésük szerint - a misszió egységes orientációt biztosít a cégen belül, mintegy fókuszpontot képezve a célokkal azonosulni kívánó szervezeti tagok számára. A misszió egyben hozzájárul az alkotó szervezeti légkör, az együttműködési készség kialakulásához és megerősödéséhez. A vízió, azaz a vállalati jövőkép fogalmi értelmezése néhány évvel később jelent meg a stratégiai menedzsment nemzetközi irodalmában. Az elméleti definíciók a víziót a cég előrevetített és kívánt jövőbeli állapotával azonosították, amely perspektivikus kép a szervezetnek egy távolabbi fejlődési stádiumát rajzolja meg. A meghatározások általában hozzáfüzték a vízió körülírásához, hogy - a misszióval szemben - ,érzelmi töltés” nem füződik a jövőkép felvázolásához (Thompson \& Strickland, 1992).

Az iparági és versenyhelyzet elemzés meröben új szempontjaira mutatott rá Porter (1980), amikor az iparági struktúra oldaláról (industry structure-based view) közelített a stratégiaalkotási folyamathoz. Vizsgálódásai szerint az üzletági stratégiáknak olyan szektorális szerkezetet célszerü tükrözniük, amely iparági feltételek között ténylegesen versenyeznek egymással a nyereségorientált szervezetek. Az iparágak és versenytársak elemzésének Porter által kidolgozott öt erőtényező-modellje újabb lehetőségeket tárt fel a stratégiaformálás számára: az 1980-as éveket a porteri fogalomkészlet és módszertani eszköztár széles körü felhasználása jellemezte a stratégiai menedzsment elméletében és gyakorlatában egyaránt (Tari, 2007).

Az 1990-es évtized elejétől figyelemreméltó szemléletváltás következett be a stratégiai gondolkodás fejlödéstörténetében. A porteri iparág- és versenyanalízisek némiképp háttérbe szorultak és a stratégiakutatók érdeklődésének homlokterébe a vállalat - korábban periferikusan kezelt - belső anyagi és szellemi eröforrásai kerültek. Az erőforrásokra alapozott felfogásmód (resource-based view, RBV) elméleti fordulata abban rejlett, hogy az új megközelítés hívei, így például Prahalad és Hamel (1990) nem a versenykörnyezet termék/piac követelményeiből, hanem a szervezet rendelkezésére álló erőforrások színvonalából indultak ki.

Az erőforrás-alapú megközelítés „elágazásának” nevezhető a valamivel később jelentkező tudásalapú nézőpont (knowledge-based view, KBV), amennyiben a tudásra úgy tekintünk, mint a stratégiailag legfontosabb 
vállalati erőforrásra (Grant, 1996). A neves stratégiaelméleti szakember értelmezésében ugyanis a rejtett (tacit) tudás a tartós versenyelőny alapvető forrása: az üzleti szervezet akkor tesz szert fenntartható versenyelönyre, ha képes rugalmasan és hatékonyan integrálni a szervezeti tagok egyéni tacit tudását.

Az iparági erőhatásokra alapozott koncepcióban jól tükröződött Porter azon felfogása, hogy kiélezett versengés folyik a vállalati szférában. A cégvilág azonban másfajta viszonylatokkal is jellemezhető - vélték azok a teoretikusok, akik a szervezetközi kapcsolatok aspektusából (relational view) vizsgálták felül a versenystratégiai elgondolás feltétlen érvényességét. Az erősödő meggyőződés, miszerint a vállalat nem elszigetelten tevékenykedik, hanem a többi szervezettel létesített kapcsolatok bonyolult hálózatában, megkérdőjelezte a stratégiaalkotás „magányos úttörö" modelljét. Elvi következetességgel Child \& Faulkner (1998) és Dyer (2000) fejtették ki, hogy a tartós versenyelőny egynémely értékes forrását az egyedi (single) vállalat határain kívül indokolt keresni.

A fentiekben vázolt, a XX. század utolsó évtizedeiben kialakult stratégiaelméleti áramlatok közös ismérve a racionális-normatív szemléletmód. Képviselői olyan nézetrendszernek tekintették a stratégiai menedzsmentet, amelynek alapgondolata szerint a vállalatvezetés időrőlidőre áttekinti cége piaci helyzetét, újraértékeli a jövőre vonatkozó elvárásait, s ennek figyelembe vételével tűzi ki, majd valósítja meg stratégiai céljait. Az így értelmezett stratégiaképzés és -megvalósítás egyértelműen normatív (preskriptív) folyamat: elöírja a kívánatos jövőbeli állapotot és számon kéri a célok megvalósulását (Chikán, 2008).

\section{A stratégiaalkotás mint szervezeti folyamat}

Egy alapvetően eltérő felfogásmód bontakozott ki a stratégiai menedzsment elméletében az 1980-as évektől, szinte a stratégiai folyamat újra értelmezéseként. A rendhagyó megközelítés hívei folyamatában törekedtek megérteni a stratégia létrejöttét. A korlátozott racionalitás elvére hivatkozva, leírni és magyarázni kívánták a nem ritkán „,menet közben formálódó” (számos esetben spontán módon keletkező, vagy utólagos felismerésekből „mintává összeálló”) cégstratégiák kialakulási folyamatát. A stratégiaalkotást sajátos szervezeti folyamatként fogták fel, példának okáért kognitív (megismerési), tanulási, tárgyalási-alkudozási, vagy passzív alkalmazkodási (reaktív) folyamatként.

A leíró-magyarázó szemléletet kezdeményező teoretikusok közül Quinn és Mintzberg érdemelnek különös figyelmet. Quinn (1980) nagyvállalati esettanulmányokból leszürt általánosításai nyomán a stratégia kialakulásának logikai inkrementalista elméletét dolgozta ki. Meglátása szerint a sikeres cégek felsőszintű vezetői fokozatosan, lépésröl-lépésre haladnak az általuk vizionált vállalati jövőkép megvalósulása felé, miközben törekednek a stratégiai döntésekhez felhasznált információk minőségének javítására, a változást ellenzők meggyőzésére, továbbá a szervezet tudatosságának, lélektani elkötelezettségének erősítésére.

Mintzberg (1987) a kézművesség metaforájával érzékeltette a stratégiaalkotás lényegi vonásait. Vállalati megfigyelései alapján a stratégia megfogalmazói (a stratégák)
- hasonlóan az anyagot kezükkel „intim” módon formáló és mozdulataikat szükség szerint improvizáló kézműves mesterekhez - szüntelenül alkalmazkodnak a környezet „meglepetéseihez”. Ekképpen a folyamatos adaptációs cselekvés során elválaszthatatlanul fonódnak össze a stratégiaformálás és -megvalósítás tudatos és spontán menedzseri döntései.

A leíró-magyarázó megközelítés egy további neves szószólója, Burgelman (1983) az autonóm stratégiai kezdeményezéseknek tulajdonított fontos szerepet a cégstratégia formálódásában: tapasztalatai szerint a szervezet alsóbb szintjeiről szorgalmazott indítványok, javaslatok eltérhettek a vállalati stratégia ,hivatalos” irányvonalától. Amennyiben egyes befolyásos csoportok vagy egyének támogatták az alulról jövő stratégiai felvetéseket, módosíthatták a már felső szinten elfogadott távlati célokat.

Quinn, Mintzberg és Burgelman leírásai azt sugallják, hogy a stratégia kialakulása valójában tanulási, kísérletezési folyamat, menetközbeni elköteleződés az irányvonal mellett. A leíró-magyarázó megközelítésnek hét áramlatát, elméleti iskoláját különböztették meg Mintzberg et al. (1998). Ezek közül egyes felfogások hanyatlani kezdtek a múlt század vége felé, más koncepciók megerősödtek, ismét más iskolák huzamosabb ideje mérvadó részei a szakirodalomnak. Fejlődéstörténeti áttekintésünkhöz - az imént tárgyalt, tanulási iskolának nevezett áramlaton kívül - három elméleti iskola kapcsolódik közvetlenül. A vállalkozói iskola (Stevenson \& Gumpert, 1985) képlékeny víziók felvázolásának tekinti a vállalkozás stratégiájának kialakulását, amely folyamatban részint a vezetői tudatosság, részint az ösztönös megérzés játszanak szerepet. A kognitív iskola (Schwenk, 1988; Huff, 1990) a stratégia formálódását a gondolkodási folyamatban lezajló megismerésre vezeti vissza, amikor a stratéga megszüri és kódolja a környező világból érkező „,inputokat”. A környezeti iskola (ezen belül az intézményi áramlat) képviselői (Miller, 1979; Oliver, 1991) a külső erők halmazának ,kiszolgáltatott” szervezet passzív alkalmazkodásában (mint reaktív folyamatban) vélik felismerni a vállalati stratégia kialakulási módozatát.

\section{A stratégiaalkotási folyamat racionális-normatív értelmezése és leíró-magyarázó megközelítése - összehasonlításban}

A stratégiai menedzsmentelmélet hazai kutatói közül Balaton (1997) elsőként hívta fel a figyelmet a vállalati stratégia formálódásának kétféle útjára. A racionális-normatív szemléletben létrehozott stratégia kifejezi a felső szintű menedzserek azon szándékát, hogy tudatosan tervezzék meg a vállalat jövőjét, s annak sikeres elérését a belső és külső feltételek alapos elemzésével támasszák alá - vélte a szerző. Ugyanakkor hangsúlyozta: a stratégiaalkotás sokkal bonyolultabb folyamat annál, mintsem pusztán egyenesvonalú lépéssorozatként lehessen értelmezni. A leíró-magyarázó irányzat követői ennek az összetett folyamatnak a megismerésére, a menet közben kirajzolódó stratégiák megértésére törekednek. Elméleti leírásaik úgy tekinthetők, mint tudományos ambíció a racionális-normatív szemléletmód kibővítésére, a hiányos stratégiaalkotási mozaikkép kiegészítésére. 
A továbbiakban, a stratégiai menedzsment utolsó negyedszázados fejlődéstörténetét a két stratégiaelméleti alapirányzat mentén mutatjuk be. Utaltunk arra, hogy Mintzberg et al. (1998) hasonló (előíró-leíró) alaptípusokból indultak ki, amikor stratégiai ,útbaigazításra” vállalkoztak a szerteágazó szakirodalom rendszerező áttekintésével és értékelésével. Ugyanilyen osztályozást fogadott el Lynch (2006): a vállalati stratégiáról írott könyvében „prescriptive” és ,emergent” fö tendenciákat különböztetett meg a stratégiai menedzsmentben.

\section{Változó stratégiaalkotás - a stratégiai menedzsment módosuló környezeti feltételei}

Az elméleti kutatók analízisei egyöntetűen állapítják meg, hogy számos kihívást jelentettek a stratégiai menedzsment számára az 1990-es évtized és az ezredfordulót közvetlenül követő évek környezeti változásai.

A gazdasági globalizáció előre haladásával még szabadabbá vált a termelőtőke és a pénztőke áramlása, növekedett a munkaerő országok között mozgása, gyorsuló ütemben bővült a javak és szolgáltatások kereskedelme, fokozódott a piacok térbeli integrációja az immár egypólusú világban. A hagyományos termelési tényezők szerepe elhalványult, $\mathrm{s}$ a tudás lépett elő meghatározó társadalmi erőforrássá (Mészáros, 2002). A tudás megszerzésének és felhasználásának alapvető infrastrukturális eszközévé vált az információtechnológia. A digitális technika alkalmazásai gyökeresen átalakították a gazdasági-társadalmi szerkezeteket és müködési folyamatokat. Különösen az internet által közvetített információs hajtóerők módosították a társadalom egészének életminőségét: az egyén, a család, a gazdasági szervezetek, az állami intézmények és más közösségek számára korábban elképzelhetetlenül gyors és kiterjedt információ-hozzáférést biztosít a világháló. Az internet révén ugyanakkor rendkívüli mértékben csökkentek az információ előállításának, tárolásának, feldolgozásának és átvitelének költségei (Bőgel, 2000).

Az új típusú vállalatról, mint tanuló szervezetről szóló könyvükben, Kocsis és Szabó (2000) a tudásalapú és információs társadalom egyik legfontosabb ismérvének jelölték meg a hálózatosodást. Úgy vélték, hogy a modern hálózati gazdaságban egy vállalat sikeres működése a tudás hálózati csomópontjaihoz történő kapcsolódás és azoktól való rugalmas elszakadás képességének tulajdonítható.

A politikai-szociális tényezők globalizálódásának jelensége is világosan kirajzolódott az 1990-es évektől. Együtt mozgás ment végbe a különböző országok politikai intézményeinek, jogrendszerének, pénzügyi szférájának és foglalkoztatási-életviteli viszonyainak hasonulásában. Közeledtek egymáshoz a jóléti állam szervezeti rendszereinek intézményi megoldásai, összemérhetővé váltak az állami kiadások, az adók és járulékok. Erősödtek a civil szervezetek világméretű mozgalmai és a jótékonysági intézmények összehangolt akciói (Marosán, 2006).

A jelzett időszakban megnőtt a nyugati társadalom szélesebb rétegeinek érdeklődése a társasági formában működő magántulajdonú szervezetek tevékenysége iránt, az egyes nagyvállalati vezetők felelőtlen üzleti magatar- tásához köthető számviteli botrányok és cégbukások nyomán (Grant \& Visconti, 2006). A bizalmi válságba került társaságirányítási rendszer megújításának jelszavával, a fejlett piacgazdaságokban szigorodott a vállalati kormányzás (corporate governance) intézményi biztosítékainak, az irányító testületeknek társadalmi kontrollja. Törvények, ún. függetlenségi szabályok, ajánlások születtek a tőzsdei cégek átláthatóságára, belső és külső ellenőrizhetőségére vonatkozóan: egyebek között a Sarbanes-Oxley Act az Egyesült Államokban, az Európai Unió ajánlásai, a brit vállalati kódex (Combined Code) és a megújult társasági törvény (Company Law Reform Act) az Egyesült Királyságban (Tricker, 2015).

\section{A racionális-normatív szemléletű stratégiai menedzsment tovább fejlődése az ezredforduló körüli évektől}

Az iparági struktúraelemzés öttényezős modellje és a versenyelöny erőforrás-alapú koncepciója: még mindig hatnak és állásfoglalásra késztetnek!

A Porter által kidolgozott, a versenyelöny fenntartását segítő öttényezős iparág-elemzési modellt többen próbálták újra értelmezni az ezredforduló tájékának változó világgazdasági feltételei között. Grove (1997) például egy hatodik erőtényezőt is figyelembe vett a versenyelmélet „,korszerüsített változatához”. Az Intel korábbi elnökvezérigazgatójának tapasztalatai szerint a hatodik eröt jelentő komplementerek olyan - más típusú üzletben érdekelt - szervezetek, amelyektöl kiegészítő termékeket és szolgáltatásokat vásárolnak a vevők. A komplementerek törekvései gyakran illeszkednek a saját üzleti tevékenység céljaihoz, ám az új technikák és technológiák módosíthatják a kiegészítők befolyásának irányultságát.

Az öt erőhatás modell kisebb-nagyobb átalakítását javasló felvetésekkel párhuzamosan néhány stratégiakutató átfogóan bírálta az iparági struktúra elemzésének „statikusságát". Szerintük az iparági környezet - a Porter-féle értelmezésben - determinisztikusan adott a vállalatok számára, bár nem abszolút módon, hanem korlátozott stratégiai mozgástér mellett. Evans és Wurster (2000) egyenesen úgy vélték, hogy az internet elterjedésével szükségképpen újra kell definiálni az öttényezős modellben adottnak felételezett iparági versenytársakat.

Az öttényezős stratégiai elemzési eszközt ért bírálatokra válaszolva, a stratégiai menedzsment elméleti kiválósága - csaknem harminc évvel az öt erőhatáson alapuló modelljének első publikálása után - egyértelműen megerősítette a nagyhatású versenykörnyezet-analízis fö téziseit. Újabb statisztikai adatelemzései nyomán Porter (2008) félreérthetetlenül leszögezte: az iparági struktúra igenis érdemben befolyásolja az ágazati jövedelmezőséget! Az iparági szerkezet tudniillik megszabja közép- és hosszú távon, miként osztják fel a szektorban létrehozott értéket az ágazat szereplői között. Fontos megállapítást tett Porter a komplementerek szerepéröl is: a kiegészítő termékek és szolgáltatások nem képezhetik az iparági jövedelmezőséget befolyásoló hatodik erőt, mert csak olyanformán befolyásolják közvetve a jövedelmezőséget, ahogyan az öt erötényezőre hatnak 
Porter versenystratégiai felfogása tulajdonképpen átörökölte a SWOT-analízis egyik dimenzióját, a külső környezeti tényezőket. A vállalati belső adottságokat (a SWOT-modell másik összetevőjét) az erőforrás-alapú megközelítés (RBV) hívei emelték át nézetrendszerükbe. Az előzményeknél felidéztük, hogy meggyőződésük szerint a vállalatspecifikus alapkompetenciák tudatos felkutatásával és kiaknázásával biztosítható a fenntartható versenyelőny. Ezt a koncepciót D’Aveni (1994) az első RBV-kritikusok között igyekezett cáfolni a hiperversenyről alkotott elméletével: a végsőkig kiélezett modernkori piaci verseny közegében gyorsan erodálódnak az alapvető erőforrások tartós járadékgeneráló tulajdonságai. A már hivatkozott Evans és Wurster (2000) hasonlóképpen azt fejtették ki, hogy a világháló alapjaiban ingatja meg a fenntartható versenyelöny másik vélelmezett biztosítékát, az erőforrás-alapú versenyfelfogást. Ugyanis viszonylagossá válik a magkompetenciák vállalathoz kötött jellege, mert az erőforrások szabadabb áramlásával még az értékesnek, ritkának és nehezen másolhatónak vélt alapvető képességek is hozzáférhetőek lesznek más cégek számára vélekedtek a szerzők.

$\mathrm{Az}$ erőforrás-alapú megközelítést bíráló nézetekre adott válaszként értékelhetők a dinamikus képességekre vonatkozó elméleti megfontolások.

A vállalati dinamikus képességek - az értelmezésüket megvilágító teoretikusok szerint - kifejezetten más szervezeti erőforrások felhasználását, adaptálását, integrálását és „újra konfigurálását” mozdítják elő a menedzseri kompetenciák hasznosításával (Eisenhardt \& Martin, 2000). A dinamikus képességek hozzájárulnak a vállalatban rejlő tudás összegyüjtéséhez, tárolásához és megosztásához, továbbá erősségük határozza meg, milyen mértékben képes a szervezet az alapvető erőforrásokat átrendezni a vevői igények szerint (Wang \& Ahmed, 2007).

Egyes nézetek szerint (O’Reilly \& Tushman, 2008) a szervezet ún. kettős képessége (organizational ambidexterity) szintén értelmezhető dinamikus képességként. Felmérések tanúsítják, hogy a kettős képesség hosszú távon eredményességet garantál a vállalatoknak, amennyiben a menedzserek szimultán aknázzák ki az erőforrásokat a meglévő üzleti területeken (hatékonyság) és tárnak fel új kompetenciákat, technológiákat, piacokat eddig nem folytatott tevékenységeikhez (hatásosság) (Taródy, 2016).

Az erőforrás-alapú nézőpont követői keresik az általuk képviselt szemléletmód érvényesítési lehetőségeit a feltörekvő iparágakban és más tevékenységi ágazatokban, illetve változatlanul foglalkoztatja öket a vállalati kompetenciák és képességek eredetének feltárása. Elméleti fejtegetéseikhez újabban felhasználják az intézményi, valamint a szervezeti magatartási megközelítések elemeit (hogyan építhetők fel például a kompetenciák és képességek a cégen belüli egyéni és csoport viselkedés talaján?). Törekvések tapasztalhatók az RBV kiterjesztett értelmezésének megalapozására: Adner és Zemsky (2006) a keresleti oldal (demand side), mint környezeti tényező koncepcionális „bevonására” tettek kísérletet. Sirmon et al. (2011) a vállalatban megvalósítandó „erőforrás hangszerelés" (resource orchestration) révén javasoltak tartós versenyelőnyt „kreálni”. Hasonló jellegü tovább fejlesz- tésként, Bromiley és Rau (2014) a gyakorlat aspektusát próbálták meg integrálni az RBV szemléletmódjába.

A fentiek alapján osztjuk a stratégiai menedzsment lengyel fejlődéskutatójának, Polowczyknak (2012) azon véleményét, mely szerint az erőforrás-alapú felfogás „még mindig befolyásos" stratégiaelméleti alapvetés.

\section{A tulajdonosiérték-szemlélet megerősödése}

A stratégiai menedzsment fejlődésének korai szakaszában a versenypozíció megszerzése, illetve a versenyelőny megtartása foglalkoztatta elsősorban a vállalati szféra szereplőit és az elméleti szakembereket. Ezt az időszakot fémjelezte Porter kezdeti munkássága, akinek a versenystratégiáról és a versenyelőnyről kidolgozott koncepciói - amint az előzőekben bemutattuk - nagy hatással voltak a stratégiai elméletre és módszertanra. Porter felfogása végeredményben az 1970-es, 1980-as évek vállalati menedzseri szemléletét tükrözte, mégpedig a rövid távú nyereségességre való törekvést. Hozzá hasonlóan, a stratégiai menedzsment más elméleti művelői szintén az operatív felső vezetés szemszögéből közelítettek a cégstratégia kérdéseihez, háttérben maradtak viszont a társasági formában működő szervezetek tulajdonosainak sajátos szempontjai. Ez az uralkodó szemlélet az 1990-es évektől kezdett fokozatosan módosulni az elméletben és a gyakorlatban egyaránt (Tari, 2015).

A vállalati gyakorlat oldaláról tekintve egyre több vállalatvezető (főként amerikai menedzser) vette figyelembe az általa irányított cég tulajdonosainak érdekeit. Az erősödő tulajdonosiérték-szemlélet egyik első teoretikusa, Rappaport (1998) különböző okokra vezette vissza a top menedzserek látásmódjának megváltozását:

* belátták az első számú vezetők, hogy önmagában véve a fogyasztói igénykielégítés nem eredményez automatikusan profitot, pusztán az árbevétel gyarapodik,

* befektetéseik révén, a részvénytársaságok csúcsvezetői a cég meghatározó egyéni tulajdonosai közé kerültek,

* a nagyvállalatoknál egyre gyakrabban kötötték a vezetői javadalmazást a tulajdonosi érték növekedéséhez,

* a cég más vállalat által történő felvásárlásának fenyegetése ugyancsak a tulajdonosi érték növelésére késztette a felsőszintü menedzsmentet,

* a csúcsvezetői pozíció megörzéséért folytatott belső hatalmi harc nem különben ösztönözte a vállalatvezetőket a tulajdonosi értékteremtésre.

Az ezredforduló körüli években egyre több, tényleges tulajdoni részesedést birtokló vagy részvényopciókkal motivált felső vezetőben tudatosodott, hogy személyes vagyoni gyarapodásuk szorosan összefügg az általuk vezetett részvénytársaság tőzsdei árfolyamával. Számukra a részvényárfolyam növekedése vált a legfőbb szervezeti céllá. Ennek megvalósulása érdekében jó néhány csúcsmenedzser élt vissza a tulajdonosi bizalommal: kihasználva a külső ellenőrzés lazaságát, a kedvező eredmények demonstrálásának szándékával meghamisították a társasági számviteli adatokat, miközben nagy összegű részvényvásárlási opciókra tettek szert.

A tulajdonosi érték (shareholder value) kategóriája a befektető tulajdonosok elvárásait fejezi ki; általában a befektetett tőke utáni, az alternatív befektetési lehetőségek- 
hez viszonyított arányos megtérülést várják el. A vagyongyarapodás minden egyes tulajdonosnak érdeke, de egy részvénytársaság lehetséges tulajdonosi csoportjai (egyéni kisbefektetők, intézményi befektetők, szakmai befektetők és mások között érdekkülönbségek, a tőkemegtérülés követelményétől eltérő preferenciák is kialakulhatnak (Copeland et al., 1994).

A tulajdonosiérték-szemlélet megerősödéséhez szervesen kapcsolódott az értékalapú vállalatvezetés (Value Based Management, VBM) koncepciójának elterjedése. Az értékközpontú vezetés olyan összetett folyamat, amelynek során a döntéseket úgy hozzák a szervezet minden egyes szintjén, hogy a vállalat értékének növelését tartják szem előtt. A folyamatos részvényesi értéknövelés célzatával a VBM kijelöli az alapvető értékteremtő tényezőket (value drivereket), megalkotja az értékmaximalizáló stratégiát, majd lebontja azt value driverekben kifejezett eredménycélokká (Black et al., 1999).

Egy későbbi tanulmányában Rappaport (2006) néhány lényeges szempont újólagos mérlegelését ajánlotta a vállalati menedzserek figyelmébe, ezzel is ösztönözve a társasági ügyvezetést a tulajdonosi érték növelésére. Érvelése szerint a vállalatértéket növelő stratégiai döntéseket akkor is érdemes meghozni, ha rövidtávon csökken a cég profitja. Óvott egyúttal, hogy a vállalatfelvásárlási tranzakcióknál elfeledkezzenek a tulajdonosi vagyon gyarapításáról, a felső vezetők javadalmazását pedig a cég hosszú távon elért eredményességével javasolta összekapcsolni.

\section{A vállalati érintettek elvárásainak érvényesítése}

A tulajdonosokon és menedzsereken kívül más érdekcsoportok is kapcsolódnak egy társas cég tevekénységéhez. Ezen érdekeltek (többek között az alkalmazottak, a hitelezők, a szállítók és vevők, a kormányzati szervek vagy a helyi közösségek) ugyanúgy a vállalat ,érintettjei”, mint a tulajdonosok és a menedzsment.

Az érintettelmélet koncepcionális születését Freeman: „Strategic management: a stakeholder approach” címü, revelációként ható könyve (1984) jelezte. A müben alaptézisként fogalmazza meg a szerző, hogy minden, a magántulajdonú vállalatban legitim érdekeltséggel rendelkező személy vagy csoport ellenszolgáltatásra tart igényt, de nem létezhet olyan érdek, amelynek érvényesítése megelőzné bármely másikét. Az elkövetkező évek során az érintettelmélet továbbfejlődésével vált ismertté és elfogadottá a stakeholder-szemlélet. Az érintettelmélet elterjedését ugyanakkor a nagyobb társadalmi felelösségvállalást hirdető gazdaságetikai nézetek megerősödése segítette elö.

Az érintettelmélet abból indul ki, hogy nemcsak a tulajdonosoknak, hanem az érdekeltek további körének is felelősséggel tartozik a gazdasági társaság. A cégnek úgy kell meghatároznia stratégiai céljait, hogy teljesítésükkel valamennyi érintett számára bizonyos fokú elégedettséget nyújtson (stakeholder value).

A tulajdonosiérték-szemlélet és az érintettelmélet látszólag kizárják egymást. Az előbbi felfogás hívei azonban elismerik az összes mérvadó érintett szempontjait azzal a meggyőződésükkel, hogy az érdekcsoportok akkor járnak a legjobban, ha a vállalat fó célja nem más, mint a tulajdonosi érték növelése. Állításukat - Könczöl (2007) elemzése szerint - a tulajdonosi érték maradékérték jellegével indokolják: a tulajdonosok csak maradék érintettként, az elsődlegesen érintett csoportok igényeinek kielégítése után jutnak hozzá saját jövedelmükhöz.

Az elsődleges érintetteket lényegi, tartós és kölcsönös reláció füzi a vállalathoz. A stakeholder-szemlélet alapján fogalmazzák meg Freeman és McVea (2005) a stratégiai menedzsment egyik alapkérdését: Hogyan érvényesülnek az elsődleges érintettek szempontjai a vállalati (társasági) stratégiában?

A racionális-normatív felfogás szerint a föbb érdekcsoportok közül a tulajdonosoknak (illetőleg az érdekeiket érvényesítő társaságirányítási testületeknek), valamint az ügyvezető menedzsereknek van közvetlen befolyásuk az összvállalati stratégia kialakítására és jóváhagyására. A vevők, szállítók, hitelezők, kormányzati tényezők és más érintettek stratégiaformáló szerepe közvetett. Például a fogyasztók „ráhatása” a stratégiai vonalvezetésre áttételesen - a vállalattól történő vásárlásaik révén - érzékelhető; ugyanígy a kormányzati szándékok is jobbára közvetve tükröződnek a társasági stratégiában - állapították meg Freeman és McVea.

$\mathrm{Az}$ érintettelméletre épül a vállalatok társadalmi felelősségvállalását (corporate social responsibility, CSR) hirdető felfogás (Anderson, 1989). Ez a gyorsan terjedő szemlélet az elsődlegesen érintett érdekcsoportokon kívül figyelmet szentel a többi stakeholdernek is a „társadalmi jólét" érdekében. Az új érdekfókuszt felismerte Porter is, aki szerzőtárssal írt tanulmányában (Porter \& Kramer, 2006) természetes kapcsolatot vélelmezett az üzleti szempont és a társadalmi érdek között. A társadalmilag felelős üzleti magatartás jegyében számos mai cég a stratégiai irányvonal részének tekinti a közösségi szerepvállalást, ideértve a környezettudatos vállalati működést, az etikus üzletvitelt a helyi közösségek támogatását, vagy a munkahelyi esélyegyenlőség biztosítását. Ezt a vállalati politikát Imre (2017) találóan önkéntes stakeholder menedzsmentnek nevezte.

\section{A vállalati kormányzás növekvő felelössége}

A vállalati kormányzás intézménye hivatott arra, hogy a befolyásoló csoportok egyenrangúságon alapuló érdekegyeztetését megvalósítsa. Angyal (2001) meghatározása szerint a vállalati kormányzás olyan felelős társaságirányítási rendszer, amelynek érdekegyeztető müködéséhez a hatalomgyakorlást társult (testületi) formában, az egyes csoportokat és személyeket illetően megosztottan, együttmüködésükre alapozva alakították ki. A definícióból következik, hogy a vállalatkormányzás „tárgyát” az érintett csoportok képezik, míg a társaságirányítás céljának a befolyásolók igényeinek kielégítése tekinthető. A kormányzás módjaként a társult (testületi) szerveződés jelölhető meg, az irányítás módszere pedig a kooperatív, egyensúlyozó stílus.

A vállalati kormányzás kialakulása a sok évtizeddel ezelőtti Észak-Amerika (USA, Kanada) gazdaságához köthető, ahol a vállalati szféra domináns szervezeti-jogi 
formája a részvénytársaság (Tricker, 2015). Ebben a szervezeti-jogi keretben elkülönültek a tulajdonosi és a menedzseri szerepek: a részvényesek átadták az ügyvezetés napi feladatait a menedzsereknek, a tulajdonosok pedig csak időleges ellenőrzési szerepet vállaltak (megbízóügynök probléma). A két érdekcsoport közé beépült az igazgatótanács (board of directors) testületi intézménye, amely grémium fö feladatául a folyamatos részvényesi érdekérvényesítést jelölték meg a gazdasági jogalkotók. A tulajdonosok-igazgatótanács-menedzserek hármas képezi a többi angolszász országban is elterjedt egytanácsos (egyszintü) társaságirányítási modellt (Bartók,2007).

A kontinentális nyugat-európai államokban az érdekérvényesítési képesség nemcsak a tulajdonosokra és a menedzserekre jellemző, hanem olyan elsődleges érintettekre is, mint a munkavállalók, a hitelező bankok vagy a beszállítók (Szintay,2001). A munkavállalói érdekképviselet hagyományos befolyása szerepet játszott például abban, hogy a német részvénytársaságok a kéttanácsos (kétszintü) vállalatkormányzási modellt alkalmazzák (Aufsichtsrat-Vorstand). A felügyelőtanácsban hosszú idő óta a Mitbestimmung (együttszavazás, egyetértés) kodeterminációs elvét követik az alkalmazotti érdekek érvényre juttatásáért. A kétszintü német rendszer honosodott meg Ausztriában, Svájcban és Hollandiában is (Dobák \& Tari,2015).

Az előbbiekben röviden kitértünk arra, hogy a társaságirányítás tényleges gyakorlata az üzleti etika számos kérdését vetette fel az ezredforduló körüli időkben. A vállalati szféra számviteli visszaéléseit feltáró elméleti szakemberek rámutattak: a társaságok igazgatótanácsai nem képviselték megfelelően a részvényesi érdekeket, nem gyakoroltak hathatós ellenőrzést a vállalati vezérigazgatók felett. A stratégiai menedzsment szemszögéből vizsgálódva, Grant és Visconti (2006) olyan amerikai és európai nagyvállalatok eseteit dolgozták fel, amely társaságok bünös részesei és egyben szenvedő alanyai voltak a nagy port felvert könyvelési botrányoknak. A szerzőpáros azt próbálta meg kideríteni, hogy az elbukott társaságok által követett stratégia megfelelt-e a környezet elvárásainak, avagy illeszkedett-e a rendelkezésre álló belső erőforrásokhoz. Összehasonlító elemzésük felfedte, hogy a vizsgált 12 cégre egyaránt jellemző volt:

- a túlzott növekedési hajlam (föként vállalatfelvásárlásokkal „kielégítve”),

- a szélsőséges diverzifikáció és

- a felelőtlen kockázatvállalás a nyereség maximalizálásáért.

Grant és Visconti megállapították összegzésül, hogy minden egyes nagyvállalatnál fókusztévesztés történt: a felső vezetés függetlenítette magát a stratégiai külső és belső elemzés követelményeitöl, szabad kezet kaptak a mértéktelen növekedéshez, a sorozatos akvizíciókhoz és a végletes eladósodáshoz.

A visszaélések megismétlődésétől tartva, az amerikai kongresszus által elfogadott Sarbanes-Oxley törvény előírta a tőzsdei társaságoknál a könyvvizsgálói függetlenséget. A hatalmi egyensúly megteremtése érdekében az USA-ban változtatásokat vittek végbe a tulajdonosokigazgatótanács-menedzserek vállalatkormányzási háromszögben (Bartók, 2007). Más országokban (így többek között Nagy-Britanniában és Németországban) ugyancsak szigorodtak a felelős társaságirányítás szabályai. Például részletesebb, szabatos elöírások láttak napvilágot a kéttanácsos német kormányzási modell ún. felügyelötanácsi mandátumának (perszonálunió) ellenőrzési szerepéröl (Dobák \& Tari,2015).

\section{Fogyasztói értékteremtés}

A fogyasztói érték (customer value) kategóriája a stratégiai menedzsment fejlődésének korai szakaszában közismert fogalom volt: a sikeres vállalati müködés zálogát a fogyasztói igények maradéktalan kielégítésében látták. Az uralkodó nézet szerint akkor valósult meg a fogyasztói értékteremtés, ha a vevők elismerték vásárlásaikkal a termékek és szolgáltatások árban kifejezett értékét. A fogyasztónak nyújtott érték már Porter klasszikusnak számító értékláncmodelljében szerepelt az utolsó, végső láncszemként. Porter (1985) a vállalatok üzletágainak (üzleti egységeinek) értékalkotó tevékenységét stratégiai szempontból lényeges fázisokra (elsődleges és támogató tevékenységek) bontotta, hogy kimutathatók legyenek az egyes üzletágak potenciális versenyelönyei.

A fogyasztói érték akkori kitüntetett szerepe olyan elméleti állásfoglalásra inspirált egyes stratégiai gondolkodókat, miszerint a fogyasztói igények kielégítése, a fogyasztói értékteremtés tekinthető az alapvető vállalati célnak. Ezt a felfogást megerősíteni látszott egy innovatív fejlemény: az előző század utolsó évtizedeiben a tömegtermelés versenyelönyét felváltotta a „tömeges testre szabás" (mass customization) korszaka, azaz a vevők igényeit maximálisan kielégítő termelés és szolgáltatás térhódítása (Szabó \& Kocsis,2002).

Mindazonáltal napjainkban általánosan elfogadott a racionális-normatív szemléletü stratégiai menedzsmentben, hogy a vállalati értékteremtés folyamatában kettős célnak kell vezérelnie a menedzsereket: értéket nyújtani a fogyasztónak és értéket létrehozni a tulajdonosoknak. Czakó (2007) érvelése szerint a kettős cél hosszú távon nem valósítható meg egymás rovására, ezért kölcsönösen kiegészítő és erősítő folyamatokként helyes értelmezni a fogyasztói értékteremtést, valamint a tulajdonosi érték növelését.

A kettős értékteremtés eszerint nem kérdőjelezi meg a vevői igény feltétlen érvényesítését a stratégiaalkotásban. Ennek tudatában vannak maguk a vállalatok: különböző tartalommal és formában fogalmazzák meg fogyasztói irányultságú küldetésüket, illetve vázolják fel jövőképüket. Az általuk kommunikált missziók és víziók jellegzetességeinek tipizálására tett kísérletet Salamonné Huszty (2000).

A fogyasztói értékítélet az utóbbi években fókuszponti jelentőségünek bizonyult a rohamosan fejlődő infokommunikációs ágazatokban. Ezt ismerte fel Moore (2002) sajátos „hídfóállás”-koncepciójával, amelynek útmutatása szerint a vevői értékelvárások különféleségére célszerű alapozni az IT-szektor piacépítését. Moore megkülönböztette az 
információtechnológiai újdonságok első lelkes vásárlóit (pionírok), továbbá a korai elfogadókat (early adopters) és a vásárlási kockázatot nem kedvelő korai többséget (early majority), valamint az újonnan piacra dobott IT-termékeket utolsóként megvásárló késői többséget és tunya vevőket.

A fogyasztói értékteremtéshez közvetlenül kapcsolódott Kim és Mauborgne (2005) értékinnováció (value innovation) felfogása A szerzők szakítottak a versenystratégia hagyományos tantételével, az érték-költség kompromisszummal: sikeres vállalatok példáival mutatták be, hogy az általuk ,kék óceán stratégiának” nevezett irányvonal egyidejüleg célozza meg a termékdifferenciálást és az alacsony költségeket. Tapasztalataik szerint az innovatív cégek túllépnek a zaklatott piaci versenytér (vörös óceán) határain azzal, hogy „,elébe mennek” a fogyasztói értékelvárásoknak olyan termékekkel és szolgáltatásokkal, amelyekre nézve még nem fogalmazódtak meg a vevői igények. Az érintetlen piaci terek (kék óceánok) megteremtésével érhető el a versenytársak teljes kiiktatása - állapították meg a nagyhatású fogyasztói értékinnováció-elmélet kidolgozói. Új könyvükben (Kim \& Mauborgne, 2017) a vevői élményciklus szakaszainak azonosítása kapcsán - Moore-hoz hasonlóan - jellegzetes fogyasztói szegmenseket különböztettek meg a ,reménybeli vevők” körében, mégpedig a vonakodó vevők, az elutasító vevők és a feltáratlan vevők csoportjait.

A tradicionális piaci versengésen egy alapvetően másfajta üzleti logikával ,emelkedtek felül” a jelenkor technológiai óriás cégei, az Apple, a Google, a Microsoft, az Amazon és a Facebook - tettek összehasonlítást az értékinnováció-elmélettel Jacobides és MacDuffie (2013). Az általuk példaként felsorolt, kiemelkedően sikeres vállalatok új típusú platformok és iparági standardok kialakításával ellenőrzést gyakorolnak a szektorban keletkező profit felett úgy, hogy az ágazati nyereség ,,ne vándoroljon” az iparágon túlra, az értékképződés távolabbi szakaszaihoz mutatták rá elemzésükben a szerzők.

Az iparági platform olyan speciális hálózat (ökoszisztéma), amelyben a közösségi stratégia egyazon színtérre „hozza össze” a fogyasztói értékteremtésben részt vevő vállalatokat és felhasználókat. A platform legfontosabb szereplöje a tulajdonos társaság, amely felel a színtéren létrejött szellemi tulajdon jogaiért és a piactér standardokkal történő szabályozásáért. A platformtulajdonos cég mellett - kiegészítő játékosokként - egymástól látszólag független szervezetek, csoportok vannak jelen a piactéren (például interface szolgáltatók, tartalomkészítő alkotók, végső fogyasztók). A platform sikerességét a résztvevők hálózati hatásereje és az általuk kölcsönösen megosztott erőforrások, információk biztosítják (Mclntyre \& Srinivasan, 2017). A vevői értékteremtés ilyenformán az ökoszisztéma értékmaximalizálásán keresztül valósul meg!

Visszatekintve a 2007-es évre, az akkori legismertebb mobiltelefon-készülék gyártók (Nokia, Samsung, Motorola, Sony Ericsson, LG) együttvéve az iparági nyereség 90\%-át mondhatták a magukénak. Abban az évben dobta piacra az Apple az iPhone-t, amely 2015-ben már az iparági profit $92 \%$-át generálta. A meghökkentő siker kulcsa: az Apple egy színtérre hozta a kínálókat és keresőket, az applikációfejlesztőket és felhasználókat. Az értékteremtés nem a hagyományos lineáris folyamatban ment végbe, hanem egy iterativ, visszacsatoláson alapuló tevékenységegyüttesben zajlott le (Van Alstyne et al., 2016).

Az Apple-platform igazában nem más, mint a cég üzletviteli módjának, azaz üzleti modelljének megújítása. A legutóbbi években számos vállalat döntött az addigi üzleti modell innovációjáról, mert jószerével ,elfogytak” a müszaki fejlesztés lehetőségei, kimerültek a termelés-szolgáltatás racionalizálásának tartalékai. Ezért - vonták le a következtetést közel 200 üzleti modellre kiterjedő felmérésük alapján Amit és Zott (2012) - a vállalatok körében megerősödött az üzletviteli mód megújításának törekvése.

Az üzleti modell a szakirodalom értelmezése szerint négy kapcsolódó összetevőből (fogyasztói értékajánlat, nyereségképlet, kulcsfontosságú erőforrások, kulcsfolyamatok) áll, amelyek együttesen teremtenek és nyújtanak értéket. Az üzletimodell-innováció pedig a meglévőtől alapvetően különböző üzletviteli mód tudatos bevezetését jelenti a cégnél (Móricz, 2007). Az üzleti modell nem azonosítható a vállalat stratégiájával, hiszen egyáltalán nem vagy kevéssé ad felvilágosítást a versenykörnyezetről, az iparági versenytársakról, a versenyelőny forrásairól. Tapscott (2001) szerint az üzleti modellt célszerü kiegészíteni a riválisokat felülmúló versenystratégiával. Némileg másként fogalmazva: az üzleti modell csak a stratégia keretébe ágyazva lehet sikeres, mármint a vállalati stratégia céljaival összhangban teremthet valós fogyasztói (és tulajdonosi) értéket (Barakonyi, 2008).

Amit és Zott (2012) vizsgálataiból kitűnt, hogy az üzleti modell megújítását alternatívaként vagy kiegészítőként tekintik a vállalatok, a meglévő termékek és termelői folyamatok innovációja helyett vagy mellett. A kutatók három különböző útját azonosították az üzletimodell-innovációnak:

- új tevékenység(ek) „hozzáadása”, illesztése az üzletvitel meglévő építőköveihez (tartalmi innováció),

- az üzleti modell elemeinek, az ,üzlet darabkáinak” újszerü összekapcsolása (strukturális innováció),

- az üzleti modell „kormányzásának” módosítása (governance innováció).

\section{A stratégia megvalósítása és végrehajtásának ellenörzése, az értékrendek összehangolása}

A stratégiai menedzsment racionális-normatív közelítésmódjának elterjedésével növekvő számban jelentek meg olyan stratégiai tárgyú könyvek, tanulmányok, amelyek már címükben is jelezték a stratégiamegvalósítási szakasz fontosságát. Az első, korai művek szerzői (többek között Hrebiniak \& Joyce,1984; Galbraith \& Kazanjian, 1986) három feladat teljesítését tartották szükségszerünek a cégstratégia sikeres végrehajtásához:

- erőforrások elosztása a stratégiai prioritások szerint, - stratégia és szervezet összhangjának megteremtése, - stratégiai változtatások menedzselése.

Ezek a vezetői feladatok, funkciók a mai kor stratégiai menedzsmentjében is okvetlenül teljesítendők (Farkas, 2005; Balaton, 2010; Csath, 2015). Másfelől a stratégia végrehajtásának értékelése a visszacsatolási szakaszhoz 
nélkülözhetetlen: a megvalósítás ellenőrzése létfontosságú annak mérlegeléséhez, vajon a felső színtü menedzsment módosítson-e a vállalati stratégián, illetőleg a végrehajtás módján.

A múlt század első évtizedeiben a pénzügyi teljesítmény mérését szolgáló egyszerübb mutató számok (eszközmegtérülési mutatók, operatív kerettervek, cash flow-kimutatások) elégséges információt szolgáltattak a fejlődő piacgazdasági vállalatok vezetőinek az eredményes irányító munkához. Később, az 1960-as, 1970-es évek nagyvállalati menedzserei olyan pénzügyi beszámolórendszer kialakítását támogatták, amely megkönynyítette számukra a belső üzletági divíziók, stratégiai üzleti egységek teljesítményének, rövid távú pénzügyi eredményességének értékelését. Az 1990-es évek derekára született meg egy stratégiai szemléletű vezetési értékelési rendszer: az elgondolás túllépett a pénzügyi szempontok egyoldalú, kizárólagos érvényesítésén, egyensúlyt teremtve a pénzügyi és a nem pénzügyi, illetve a visszatekintő és az előrejelző mutatók, értékelési szempontok között.

A Balanced Scorecard (BSC) alkotói (Kaplan \& Norton, 1996) egy kiegyensúlyozott stratégiai mutatószámrendszer kidolgozására és egyben új stratégiai menedzsmenteszköz felhasználására törekedtek. A vállalati teljesítményt négy nézőpontból (pénzügyi szempontok, vevői elégedettség, működési folyamatok, tanulási-fejlődési kompetenciák) ragadták meg azért, hogy ez az egyszerü teljesítményértékelési módszer segítséget nyújtson a gazdasági társaságok és más szervezetek stratégiai céljainak lebontásához és megértetéséhez, továbbá támpontokat adjon a stratégiamegvalósítás ellenőrzéséhez. A BSC tulajdonképpen összehangolja a tulajdonosi és fogyasztói értékrendeket a vállalati működés folyamataival és a szervezet képességeivel!

A Balanced Scorecard gyakorlatiasan ,fordítja le” a vállalat küldetését, jövőképét és alapértékeit konkrét célokra és feladatokra a stratégiai térkép (valamint a stratégiai költségvetés) segítségével. A kiegyensúlyozott mutatószámrendszerre épülő, az ok-okozati kapcsolatokat bemutató stratégiai térkép illusztratív keretként ábrázolja, miként köti össze a vállalati stratégia az anyagi erőforrásokat és az immateriális javakat az értékteremtö folyamatokban (Kaplan \& Norton, 2004).

A BSC pénzügyi mutatói között Kaplan és Norton szerepeltettek egy már népszerűvé vált, hozzáadott érték típusú mutatót, az EVA-t. Ez a tulajdonosi értéket kifejező teljesítménymérési mutató, a gazdasági hozzáadott érték (economic value added) megadja azt az értéket, amivel a vállalat profitja felülmúlja a cég teljes tőkeköltségét. Az EVA tehát figyelembe veszi a tevékenység lekötött tőkéjének összes költségét, s akkor mutat pozitív értéket, ha a gazdasági társaság nagyobb eredményt ér el, mint amenynyi a számára tartósan juttatott össztőke elvárt hozama (Stewart, 2013).

Becker et al. (2005) szerint az EVA-mutató vázolt jellege, szemlélete a magyarázata annak, hogy kiváltképpen alkalmas a stratégia-teljesítmény összefüggés elemző értékelésére.

\section{A leíró-magyarázó szemléletű stratégiai menedzsment fejlődése az ezredforduló körüli évektől (példaként négy markánsan jelentkező, illetve megerősödő elméleti áramlat bemutatásával) \\ Vállalati stratégia és kollaboratív stratégia - magatartástudományi nézőpontból}

Megelőzően tárgyaltuk, hogy az ezredforduló körüli években számos tőzsdei vállalat beszámolóját kérdőjelezték meg a pénzügyi kimutatások manipulálása miatt. Az ismétlődő számviteli botrányok okainak feltárásánál óhatatlanul került reflektorfénybe a cégvezetők emberi magatartása, etikai viselkedése. Az újonnan jelentkező, magatartástudományi nézőpontú stratégiafelfogás elméleti gyökerei a magatartási (avagy viselkedési) közgazdaságtanra (behavioral economics) vezethetők vissza.

Miként illeszthető be az emberi magatartás a közgazdaságtani diszciplínába? Hogyan vehetők figyelembe az indulati mozgatórugók a közgazdasági elemzésben? Kahneman et al. (1982) úttörő munkássága adta meg az első válaszokat ezekre a kérdésekre. Kahneman és szerzőtársai többek között jellemezték az individuális magatartás olyan kognitív visszáságait, anomáliáit, mint az érvényességi elfogultság és a reprezentativitási elöítélet. Az előbbi fogalom azt fejezi ki, hogy az emberek - amikor döntéseket hoznak - többnyire túlértékelik az általuk személyesen tapasztalt pillanatnyi, látványos jelenségeket. Ugyanígy szubjektíve nagyobb jelentőséget tulajdonítanak azoknak az eseményeknek, illetve dolgoknak, amelyek valamilyen okból erőteljes hatást gyakorolnak rájuk. A reprezentativitási elöítélet kategóriája viszont arra utal, hogy az egyének következetesen félreértelmezik az emlékezetükben időbelileg közelebbinek tünő jelenség-valószínüségeket.

A magatartástudományi közelítésű stratégiafelfogás (behavioral strategy) - szorosan kapcsolódva az elméleti előzményeknél jelzett kognitív iskolához - integrálja az emberi megismerés, észlelés és érzelem, valamint a szervezeti magatartás és a társadalompszichológia elemeit a stratégiai menedzsment elméletébe és gyakorlatába (Powell et al., 2011; Gavetti, 2012). A koncepció a stratégiai folyamat lélektani vonatkozásainak hangsúlyozásával kísérel meg hozzájárulni olyan releváns kérdések árnyaltabb megválaszolásához, mint:

- Mely okok miatt követnek eltérő stratégiákat és alakítanak ki eltérő szervezeti struktúrákat a vállalatok?

- Miért érnek el különböző stratégiai teljesítményeket az egymással rivalizáló társaságok?

- Hogyan képesek eredményesen gazdálkodni merőben eltérő stratégiákat követő szervezetek hasonló külső környezetben?

Ennek az elméleti vonulatnak a jegyében vizsgálták meg Lovallo és Kahneman (2003) az ezredforduló tájékának vállalati kudarcait, különös tekintettel a cégvezetők észlelési elfogultságára (cognitive bias) és önhittségére (hubris). Amint a pszichológiai indíttatású kutatás kimutatta, a felső vezetők stratégiai döntéseit számos esetben befolyásolták elöítéletek, egyoldalúságok, ellenérzések, kitalációk, vagy illogikus értelmezések. A grandiózus 
vállalati stratégiai elképzelések születésénél például a vezérigazgatók (és a döntés-előkészítő menedzsmentteamek) nem egyszer túlzottan optimistán becsülték meg a várható hasznot, míg a költségeket ,alátervezték” (tervezési téveszme, planning fallacy). Az indokolatlan optimizmust táplálta továbbá a saját eminens képességekbe vetett hit, az önbizalom túltengése, de közrejátszott a versenytársak erősségeinek lebecsülése is.

A McKinsey tanácsadó cég egy későbbi felmérésének keretében Lovallo és Sibony (2010) arra következtetésre jutottak, hogy még a leginkább rátermettnek ismert cégvezetök stratégiai elhatározásait is befolyásolta a kognitív elfogultság: az általuk kezdeményezett akvizícióknál és vállalategyesítéseknél rendre elmaradtak a szinergikus hatások, a nagy beruházási projekteknél pedig több ízben jelentősen túllépték az idő- és a költség kereteket.

A kognitív vezetői elfogultság tipikus példájaként idézhető fel a Mercedes-modelleket előállító német Daimler-Benz és az amerikai Chrysler autógyár megafúziója. A Daimler-Benz AG igazgatóságának elnöke és a Chrysler Corporation elnök-vezérigazgatója az 1990-es évtized vége felé jelentették be a két óriáscég egyesülését, DaimlerChrysler néven. Az új konszern társelnökei a világ legnagyobb gépkocsigyártó társaságát vizionálták a XXI. század évtizedeire. Az egyenlők összeolvadásaként (merger of equals) meghirdetett fúzió előkészítésére szokatlanul kevés időt fordítottak, a felső szintü német és amerikai menedzserek szük körének bevonásával (Tari, 2005).

Az egyesült DaimlerChrysler első évének összevont pénzügyi adatai igazolni látszottak a fúzió célszerüségét. A kedvezőnek tetsző eredményeket túlértékelve, az egyesített német-amerikai menedzsment indokoltnak látta felfelé módosítani az előirányzatokat. A túlzott optimizmust tükröző tervmódosítást követően nem sokkal azonban, átszervezést jelentett be a DaimlerChrysler vezetése. Következmény: a részvénytársaság tőzsdei árfolyama csökkenni kezdett a Wall Streeten. Mindazonáltal a társelnökök továbbra is vonzó perspektívaként kommunikálták a „broad-based transportation company” elnevezésű jövőképüket.

Néhány hónap múlva, az egyesített konszern amerikai társelnökének - korábban egyeztetett - visszavonulásával felerősödött a német befolyás a Chryslernél. A DaimlerChrysler új első számú menedzsere, a német Schrempp magabiztosan jelentette ki: „A jövőben valamennyi piaci szegmensben jelen kívánunk lenni, a világ legnagyobb autógyártójaként!” Időközben a Chryslernél komoly gazdálkodási nehézségek mutatkoztak, s ez ismét kihatott a vállalatcsoport részvényeinek árfolyamára. Az intő jelek ellenére Schrempp kitartott a „global giant” elképzelés mellett, folytatva agresszív terjeszkedési irányvonalát addig, amíg a DaimlerChrysler igazgatósága és felügyelőtanácsa - a Mercedes részlegeknél is kezdődő veszteséges termelés miatt - meg nem vonta töle a bizalmat. Ezt követően az új német vezetésnek csak tetemes deficittel sikerült megszabadulnia 2007-ben a Chrysler autógyártól, mint ballasztként tekintett ,idegen” szervezeti egységtől (a stuttgarti központú részvénytársaság Daimler AG néven folytatta gépjármügyártó tevékenységét).
Az elméleti előzményeknél röviden kitértünk arra, hogy lendületet vett az 1990-es évektől elterjedt stratégiai szövetségek elméleti kutatása. A szakemberek egyfelől összehasonlító elemzésekkel mutatták be a gyakorlatban kialakult vállalati együttmüködések tartalmi-formai jegyeit, másfelől iránymutató célzattal dolgozták ki, milyen ésszerü lépések, tevékenységi fázisok szükségesek a sikeres stratégiai szövetség létrehozásához és müködtetéséhez (Tari, 1998).

Az utóbbi években a leíró-magyarázó stratégiai menedzsmentelmélet egyes képviselői a kollaboratív stratégia magatartási vetületeire világítottak rá (behavioral alliance strategy). Közülük Mellewigt et al. (2017) azt tárták fel, hogyan befolyásolják a szövetségek létrejöttét és menedzselését az individuális résztvevők jellemvonásai, motivációi, preferenciái, továbbá a kognitív folyamatokban megnyilvánuló problémaértelmezési és döntéshozatali képességei, valamint tanulási adottságai és felejtési szokásai.

\section{Az intézményalapú megközelítés}

A leíró-magyarázó jellegü elméleti áramlatok közül, a XXI. század első évtizedében észrevehetően „elöretört” az intézményalapú megközelítés. Ez a nézőpont (institution-based view) az állam és társadalom intézményi, kulturális, etikai vetületeire fokuszál a vállalati stratégiaalkotás és - megvalósítás kérdései kapcsán. A megközelítés teoretikus alapjának a leíró-magyarázó szemléletű környezeti iskolát és a szervezetszociológiából sarjadt intézményi elméletet tekintik: az utóbbi nézetrendszer a szervezetekre nehezedő intézményi nyomást írja le, sajátos analízis-eszközeivel (Guerras-Martin et al., 2014).

Az intézményi elmélet egyik jeles képviselője, North (1990) a „társadalom játékszabályainak” nevezte az intézményeket, amelyek rendeltetésszerüen csökkentik a gazdasági-társadalmi szereplők bizonytalanságát: jelzést adnak, mi tartozik a legitim cselekvések tartományába és mely ténykedés ütközik korlátokba. Scott (1995) regulatív, normatív és kulturális-kognitív intézményeket különböztetett meg. Oliver (1991) azt emelte ki, hogy az intézményi formációk nem maradnak változatlanok, mert a szervezetek különféle „stratégiai válaszokkal” reagálnak az institucionális nyomásokra, visszahatva ilyenképpen az intézményi berendezkedésre.

A szociológiai alapvetésü intézményi elméletnek kifejlődött az utóbbi években egy társtudománya, nevezetesen a közgazdaságtant, a jogi szaktudást, a szervezetelméletet, a politikatudományt, a szociológiát és az antropológiát interdiszciplináris koncepcióvá ,gyúró” intézményi közgazdaságtan (institutional economics). Felsmann (2016) mutatott rá egy tanulmányában, hogy az intézményi szempontokat érvényesítő stratégiaelméletben az „intézményalapú nézőpont” kifejezés terjedt el az „intézményi elmélet”, „intézményi közgazdaságtan” elnevezésektől való fogalmi megkülönböztetés célzatával.

Az intézményalapú nézőpont úgy tekint a stratégiai menedzseri döntésekre, mint az intézmények és vállalatok dinamikus interakciójának eredőjére, a formális és informális intézmények tükröződésére. A felfogás szerint nemcsak az iparági struktúrához és a szervezeti erőforrásokhoz igazodó vezetői megfontolások befolyásolják a 
stratégiai választásokat, hanem az intézményi hatások is közre játszanak a stratégiai döntéshozatali folyamatban. Olyannyira nem pusztán háttérfeltételt képez az intézményi rendszer Peng et al. (2009) szerint, hogy - az öttényezős porteri modell és az erőforrás-kiaknázás RBV koncepciója mellé - javasolták egy harmadik tartópillér beépítését a stratégiai menedzsment elméletébe, éspedig az intézményi perspektíva bázisán. Annál is inkább szükségszerű az intézményalapú nézőpont érvényesítése, mert a nemzeti intézmények közvetlenül határozzák meg a stratégiai folyamatot - vélték Ingram és Silverman (2002). A stratégiai menedzsment új intézményi szempontjairól szerkesztett könyvükben a szerzők egyértelmüen cáfolták Porter paradigmatikusnak nevezhető versenyelőny-modelljét, hiszen a „five forces” logikája szerint az intézményi nyomás (kitüntetetten a kormányzati politika) csak közvetve befolyásolja az iparági jövedelmezőséget azáltal, hogy az öt erőtényezőn keresztül hat.

Az intézményalapú megközelítés mellett érvelök a gyakorlatból vett példákkal törekednek igazolni elméleti hipotéziseik helyességét. A szakirodalomban megkülönböztetett figyelmet keltett egy széles körü felmérés, amely Crossland és Hambrick (2007) nevéhez füződik. Az USA, Németország és Japán cégvilágából egyaránt száz társaságot vontak be mintájukba, 15 éves időszakot felölelően: a vállalatokat három, feltételezhetően hatást gyakorló intézményi tényező (nemzeti értékek, társasági tulajdonosi szerkezet, vállalatkormányzás rendszere) alapján hasonlították össze.

A következő elméleti hipotézist fogalmazták meg a kutatók: a minta amerikai társaságainak csúcsmenedzserei (CEO-k) nagyobb stratégiai mozgástérrel befolyásolhatják a vállalati teljesítményt (pozitív vagy negatív értelemben), mint a másik két ország vállalatainak vezetői, elsősorban a nemzeti intézményeknek tulajdoníthatóan.

Korszerü matematikai-statisztikai összehasonlító módszerekkel mutatták ki Crossland és Hambrick, hogy a három intézményi tényező az amerikai vezérigazgatókra „nehezedett” a legkevésbé. A német társaságokat korlátozó intézményi nyomás erőteljesebbnek mutatkozott: koncentráltabb (főleg banki érdekeltségü) tulajdonosi szerkezet mellett, a német csúcsmenedzserek viszonylagosan szűkebb stratégiai mozgástérrel rendelkeztek, föként a kéttanácsos (Aufsichtsrat-Vorstand) társaságirányítási rendszernek és a munkavállalói érdekképviseleti szisztémának (Mitbestimmung) tulajdoníthatóan. A japán vállalati vezetők stratégiai döntéshozatali önállósága bizonyult a leginkább korlátozottnak, kiváltképp a nemzeti hagyományok, illetve a keirecu-k (vállalatcsoportok) belső testületi kontrollmechanizmusa következtében.

Mindent összevetve, az empirikus vizsgálat erős bizonyossággal (strong, robust evidence) támasztotta alá, hogy az intézményi tényezők befolyása az amerikai vezérigazgatóknál érződött a legkevésbé, míg a japán menedzserek stratégiai mozgásterét szükítették leginkább az intézményi „nyomások”. Crossland és Hambrick még hozzáfüzték a következtetésekhez: a felmérés eredményei konzisztensek a japán vállalati stratégiák közismerten homogén, egymástól csekély mértékben eltérő jellegével!

\section{A stratégiai vállalkozáselmélet}

Közismert, hogy a vállalkozáselmélet közgazdaságtani gyökerei Schumpeterig nyúlnak vissza. Felfogása szerint a gazdasági növekedés fő motorjai a vállalkozók, akiknek „kreatív rombolása” hajtja előre a kapitalista rendszert. A Schumpeter nyomdokait követő osztrák vállalkozáselméleti iskola egyik képviselöje, Kirzner (1979) úgy tekintett a piacokra, mint az individuális vállalatok által létrehozott új termékek, új technológiák és új kombinációk versenyközegére, ahol az uralkodó tendencia nem más, mint az „a priori” ismeretlen lehetőségek szüntelen vállalkozói keresése és megragadása. Ebben a közelítésben az iparági és intézményi kontextus egyáltalán nem adott a vállalkozások számára, hanem a szakadatlan vállalkozói akciókban tárulnak fel az átmenetileg jelentkező lehetőségek. Ezen alkalmak felismerésével és kihasználásával születnek az innovatív fogyasztói értékajánlatok (Jacobson, 1992).

A fenti elméleti megfontolásokból vezethető le a stratégiai vállalkozás (strategic enterpreneurship) alapgondolata, amely összekapcsolja a vállalkozó személyiség merészen kreatív magatartásformáját a racionális stratégiai menedzsment versenyelőnyre fokuszáló szemléletével.

Korábban, a vállalkozáselmélet és az előíró szemléletü stratégiai menedzsmentelmélet jórészt egymástól függetlenül fejlődtek, noha - amiként Mintzberg et al. (1998) rámutatnak - mindkét áramlat az első számú vállalati menedzsertől ,eredeztette” a stratégiaalkotást. A vállalkozói iskola (entrepreneurial school) azonban a vállalkozó intuitív személyiségére összpontosított, a függetlenségre való törekvésre, az akaratérvényesítésre és a belső szükségletből fakadó teljesítményigényre. Az iskola képviselői alapvető kategóriaként kezelték a víziót, a vállalkozó fejében ösztönösen formálódó jövőképet. A stratégiai menedzsmentelmélet racionális-normatív irányzata ezzel a leadership ,köntössel” szemben - mint láttuk - következetesen állította elötérbe a stratégiai folyamat formális jellegét, az irányzat teoretikus fejlődését pedig végig kísérte a versenyelőny elérésére és tartósítására irányuló szándék.

McGrath és Macmillan (2000) a vállalkozói gondolkodásmódról írott könyvükben vetették fel a vállalkozói személyiség és a stratégiai perspektíva integrálásának eszméjét. A vállalkozó lehetőségkereső (opportunity-seeking) viselkedését szervesen egészítené ki a versenyelőnykeresés (advantage-seeking) nézőpontja - vélekedtek a szerzők. Hasonlóan gondolkodtak Ireland et al. (2003): egy új stratégiai vállalkozáselmélet a stratégiai szemlélet egyidejü érvényesítésével adjon ösztönzést a vállalkozói lehetőségek azonosítására és megragadására. Hozzájuk csatlakozva Madhok és Marques (2014) az akcióalapú szemléletet hangsúlyozták: szerintük a versenyképesség magyarázó tényezői között feltétlenül indokolt figyelembe venni a vállalkozói ,fürgeséget”.

\section{A stratégia mint gyakorlat}

Az ezredforduló környékén jelentek meg a stratégiai menedzsment nemzetközi irodalmában azok az első tanulmányok, amelyek a vállalati stratégiát szokatlanul újszerű nézőpontból, a praxeológia (helyes cselekvés tana) oldaláról közelítették meg. 
Korábban széles körben elfogadott volt a stratégiakutatás tartalom és folyamat szerinti felosztása (Balaton, 1997):

- a stratégia tartalma azt fejezi ki, hogy mi a stratégiaalkotás eredménye (célok és eszközök),

- a stratégia folyamata arra utal, hogy miképpen formálódik a stratégia (áttekintő tárgyalásmenetünk szerint: kialakítják vagy kialakul).

A stratégia mint gyakorlat (strategy-as-practice) koncepció feloldani kívánta az előbbi csoportosítások közötti választóvonalat: az áramlat képviselői azonosították a stratégiát mindazzal, amit ,a szervezet cselekszik”, avagy amit a stratégia ,gyakorlói” (practitioners) tesznek. Ez a tevékenységalapú (activity based) értelmezés mindenkit „stratégának” tekint, aki napi munkájával hozzájárul a vállalati teljesítményhez. A stratégia nem más, mint ahogyan a szervezeti szereplők átültetik a stratégiát (strategizing) a gyakorlatba (Jarzabkowski, 2005).

Az új megközelítést többen üdvözölték a stratégiai menedzsment elméleti müvelői közül mondván: a tevékenységalapú felfogás figyelemreméltó hozzájárulás a tudományág fejlődéséhez. Más szakemberek élesen bírálták a vállalati stratégia ilyesfajta tág értelmezését, kifogásolva a „strategy-as-practice” koncepció elvont, homályos jellegét. Ismét más teoretikusok (Hrebiniak \& Joyce,2005) azt vetették a praxisközpontú felfogás híveinek szemére, hogy megengedhetetlenül „egybemossák” a stratégia kidolgozását és a stratégia megvalósítását, egyazon jelenségként (the same thing) kezelve a stratégiai folyamat két alapvető összetevőjét.

A stratégia mint gyakorlat felfogás továbbfejlődésével - úgy tűnik - erősödött a megközelítés „kézzelfoghatóbb” értelmezésének szándéka. Egy későbbi tanulmány (Whittington et al., 2011) a stratégiai folyamat fejlődését a sokáig ,bizonytalan” foglalkozásúnak tekintett professzionális stratégiai team szemszögéből láttatja. A cikk szerzői ,,professzionálisnak" nevezik a vállalati stratégiai tervezőket, továbbá a külső stratégiai tanácsadókat, akik egyaránt a stratégiaalkotás ,első vonalában” tevékenykednek. Ezek a szakértő munkatársak egy bizonyos időszakban (az 1980as évektől az új évszázad kezdetéig) kikerültek a stratégia „,academic” folyóiratainak látómezejéből.

Itt az idő, hogy újra felfedezzük a stratégiai tervezőket - érveltek a szerzők -, mert a formális stratégiai tervezési elemek csökkenésével, a szervezeti decentralizáció elöre haladásával, a stratégia „nyitottabbá” válásával gyökeresen megváltozott a stratégiai munkafolyamat jellege. A változás jeleként a tanulmány hivatkozik a tervező apparátusok vállalati megújhodására: e részlegek irányítását több helyütt az újonnan kinevezett Chief Strategy Officerek látják el. Megjegyzendő, hogy néhány évvel korábban Kaplan és Norton (2005) hasonló fejleményröl számoltak be a stratégiaimenedzsment-irodák (offices of strategy management, OSM) szerveződése kapacsán.

A ,stratégia mint gyakorlat" elméleti áramlat egyik mellékvonulatának tekinthető a stratégia kommunikációját hangsúlyozó nézőpont. Ez a megközelítés (Barry \& Elmers, 1997) a stratégiát diszkurzív-narratív formaként értelmezi: kitüntetett szerepe van a stratégia hihetőségé- nek, elfogadhatóságának, mélyebb érthetőségének, valamint hatáskeltő story-jellegének. A stratégiai folyamat elbeszélő és megértető felfogása tudatosan használja fel a nyelvi interakciókat, a történetelmondást (storytelling) a szervezeti tagok befolyásolására, cselekedeteik ösztönzésére és „narratív szükségleteik kielégítésére.”

A stratégia mint diszkurzív-narratív megnyilatkozás - vallják a rendhagyó értelmezést követő stratégiakutatók - valahol a történelmi regény, a színházi dráma és az önéletrajz között helyezhető el. Ez a gondolkodásmód „erőtényezőként” kezeli a stratégiáról folytatott közös beszélgetés, társalgás nyelvezetét, amelyet a menedzserek használnak fel a stratégia közvetítésére és elfogadtatására.

Fejlődéstörténeti vizsgálódásunk lezárásaként jegyezzük, hogy - tekintettel a napjainkban is gyarapodó vállalatstratégiai irodalom terjedelmességére - lemondtunk a vadonatúj írások feldolgozásáról.

\section{Túlhaladott-e a stratégiai menedzsment, különös tekintettel a 2008-2009-es pénzügyi válság és gazdasági recesszió vállalati stratégiaalkotási tanulságaira? Indokolt-e paradigma váltás a tudományterületen? Megkérdőjelezhető tudományági létjogosultság vagy a stratégiai menedzsment elméleti foglalatának belső megújhodása}

A racionális-normatív szemléletű stratégiai menedzsmentelmélet hazai szaktekintélye, Barakonyi (2000) úgy ítélte meg teoretikus munkássága és oktatási tapasztalatai alapján, hogy a tudományterület szemléletmódja „napjaink egyik legjobbnak tartott stratégiaalkotást és -megvalósítást segítő koncepciója". Egyszersmind figyelmeztetett: a stratégiai menedzsment nem csodaszer; elmélete és módszertana nem kezelhető a sikeres vállalati múködést feltétlenül garantáló modellek és eljárások csalhatatlan gyüjteményeként.

A figyelmeztetés időszerünek bizonyult, mert az ezredfordulós eufória lecsengése, a dot-com epizód és a 2001. szeptemberi terrorcselekmények okozta válsághangulat megkérdőjelezték a stratégiák - racionalitásra alapozott - érvényességét. Az EBF (European Business Forum) akkori jogos körkérdése (2001) választ várt a felkért szakértőktől: tekinthetők-e még a vállalati víziók és missziók a cégmüködés helyes iránytüinek?

A válaszadók - neves elméleti kutatók, vezetési tanácsadók, üzletemberek - egyöntetüen a tudatos stratégiaalkotás változatlan értékét hangsúlyozták. A prominens hozzászólók egyike, Porter így fogalmazott: „Ezt a pillanatot kell megragadnunk a stratégia újra felfedezésére!” Porter állásfoglalását megerősíteni látszott egy nem sokkal előbb végzett, vállalatok százaira kiterjedő felmérés. Bowman és Helfat (2001) matematikai-statisztikai elemzési módszerekkel mutatták ki, hogy pozitív korreláció létezik a rendszerint írásos formába öntött cégstratégiák és a megjelölt irányvonalat követő vállalatok eredményessége között.

A következő néhány éves időszakban folyamatosan fejlődött tovább a stratégiai menedzsment szakterülete, ámbár „forradalmi” változást nem hoztak a XXI. század első évei. Vélhetőleg ezt a fordulatot hiányolta Hermann 
(2005), aki szerint igény érzékelhető a hiperverseny feltételei között egy alapvetően új stratégiai nézetrendszer (dominant design) kialakítására. Más fejlődéskutatók ezzel szemben úgy ítélték meg, hogy a stratégiai menedzsment viszonylag fiatal tudományterülete nem húzhatja magára egy uralkodó teória vagy módszertan ,kényszerzubbonyát" (strait-jacket). Nag et al. (2007) inkább úgy ítélték helyénvalónak, ha a stratégiai menedzsment felmutatja kollektív identitását, illetve megkülönböztető jegyeit azzal, hogy körül írja képlékeny tudományági határait és érzékelteti a vele járó plurális jelleget.

Tény ugyanakkor, hogy a pénzügyi és gazdasági világválságot közvetlenül megelőző évek stratégiai szakirodalma egyáltalán nem vetette fel egy esetleges jövőbeli krízis vállalati forgatókönyveinek kidolgozását, mint lehetséges változatot. A stratégiai menedzsment fejlődését évtizedek óta kutató és oktató Mészáros (2015) csalódottan számolt be arról, hogy - nagyszámú írást elolvasva - ,a világ vezető stratégiai menedzsment folyóirataiban nemigen sikerült olyan tanulmányt találni, amelyik ezen $>$ felkészítő hadmüveletre $<$, mint reális stratégiai alternatívára, annak módszertani támogatására ráirányította volna a figyelmet" (p. 101). Tanulságos emlékeztetőül tette hozzá a szerző: a nagy gazdasági társaságok, multinacionális cégek egyoldalúan a divatos növekedési stratégiát részesítették előnyben, főként a kockázatos fúziós és felvásárlási ügyletek révén.

Polowczyk (2012) kutatásai szerint a világválságot röviddel követően még nem lehetett kimutatni a krízis közvetlen „lecsapódását” a stratégiai menedzsment elméletében. A válság hatásait elemzö, szervezeti szintü tanulmányok jobbára azt vizsgálták, miként reagáltak gyakorlatilag a vállalatok arra a globális méretű recesszióra, amelynek káros következményei messze felülmúlták a három évtizeddel korábban kialakult regionális válságok veszteségeit. Az elemzők megállapították, hogy a 20082009-es válság alatt szinte kizárólag a költségcsökkentés stratégiája érvényesült (háttérbe szorítva a minőséget), de előfordultak kartellezések, fizetési késedelmek, illegális foglalkoztatások. Elvétve végeztek egyes vállalatok innovációs célzatú beruházásokat is, számítva a kereslet későbbi megélénkülésére.

Elméleti síkon Ghemawat (2010) az elsők között gondolta át a válság stratégiaalkotási tanulságait. A globális vállalati stratégiák addigi alkalmazását elemezve arra a következtetésre jutott, hogy a gazdaságos termelést biztosító standardizálás mellett, a jövőben fokozott figyelmet érdemes szentelni a lokális, helyi igények kielégítésének. A multinacionális konszernek kívánatos tevékenységi diverzifikációja egyben a szervezeti kultúrák kohéziót erősítő szerepét is felértékeli - vetítette előre a szerző.

Hong és Doz (2013) szerint a kétféle (globális-lokális) szempont következetes érvényesítését jól példázza a párizsi központú L'Oréal kozmetikai óriáscég kutatási-fejlesztési stratégiája. A L'Oréal Paris úgy biztosítja a szervezeti integráció és a regionalitás összhangját az iparág kritikus funkcionális területén, az új termékek fejlesztésénél, hogy a sokszínű helyi kulturális háttérből „toborzott” munka- erőt szép számmal foglalkoztatja időlegesen a központban. A különböző földrajzi térségekből érkező leányvállalati munkatársak két-három éves központi fejlesztési gyakorlat után térnek vissza saját régiójukba, mint funkcionális igazgatók vagy márkamenedzserek.

Az elméleti tanulságok levonásának újabb mozzanatára következtethettünk, amikor a vezető amerikai stratégiaelméleti folyóirat, a Strategic Management Journal különszámot jelentetett meg 2010 végén az átmeneti (transient, temporary) versenyelőny értelmezéséről. A special issue bevezető tanulmányában D’Aveni et al. (2010) a fenntartható versenyelőny két klasszikus modellje (öt eröhatás és RBV) helyett az átmeneti versenyelőnyök megragadásának alternatíváját vetették fel. Hogyan, mi módon versenyezzenek a vállalatok, ha a cégspecifikus elönyök erodálódnak? Erre az időszerű kérdésre Wiggins \& Ruefli (2002) és McGrath (2013) úgyszintén keresték a választ. McGrath kézzelfogható javaslata: a tartósabb vezető piacipozíció-őrzés érdekében az újabb és újabb átmeneti előnyök megteremtése, illetve kihasználása a követendő vállalati stratégia. Kétségtelen, hogy a fenntartható versenyelőny teóriájának megkérdőjelezése egy korábban általánosan elfogadott stratégiaelméleti koncepció cáfolatát jelentette D' Aveni és társai, Wiggins \& Ruefli, valamint McGrath részéröl.

A pénzügyi és gazdasági válság immár egyértelmü tükröződéseként lehetett értelmezni azt a vitát, amely a jelenkori kapitalizmus reformjáról bontakozott ki, az intézményi rendszer szükségszerü átalakításának vezérgondolatával. Porter indokoltnak érezte, hogy (szerzőtárssal publikált) tanulmányban (Porter \& Kramer, 2011) lépjen túl a felelős társaságirányítás (CSR) elvein, s újfajta értékteremtési elméletet fogalmazzon meg. Eszerint a gazdasági értékalkotásnak magában kell foglalnia a társadalom egészének szóló értékteremtést is: ez a megosztott értékképződési (shared value) folyamat adhat lendületet az üzleti innováció és növekedés új hullámának. Barton (2011) amellett tett hitet a vitában, hogy a megújuló hosszú távú (longterm) kapitalizmus a jövő társadalmi prosperitásának legerősebb „motor-biztosítéka” lesz. Martin (2010) úgy vélte, hogy a kapitalizmusnak egy korábbi szűk, haszonelvű értelmezése akadályozta meg az üzleti tevékenység ,kiteljesedését” a társadalom széles rétegeinek javára.

Az örökifjú Porter figyelmét nem kerülte el az „okos, kapcsolódó termékek" (smart, connected products, SCP) viharos gyorsasággal terjedő alkalmazása sem. Az IT-fejlődés által forradalmasított produktumok módosítják az iparági verseny jellegét, következésképp a stratégia irányultságát is. Az új funkcionalitás, a termék vagy szolgáltatás jóval nagyobb teljesítménye és megbízhatósága szétfeszítik az eddig ismert iparági határokat, illetve értékláncokat. Porter és szerzőtársa, Heppelmann (2014) részéről magától értetődően vetődtek fel a vállalati menedzsereknek szánt kérdések az új helyzetben, amikor az információtechnológia a termékek integráns részévé válik: Hogyan változtassuk meg üzleti modellünket? Belépjünke új üzleti területekre? Kiterjesszük-e a vállalat tevékenységi határait? 


\section{A stratégiai menedzsment (mint önálló tudományterület) tárgya és feladata nem kérdőjeleződött meg!}

Porter és Heppelmann jellegzetes stratégiai orientációjú kérdései arról győznek meg bennünket, hogy napjainkban is hasznosíthatónak, alkalmazhatónak fogadhatók el a stratégiai menedzsment kategóriái, koncepciói, módszertani eszközei (az adott időszak követelményeihez adaptálva). Jóllehet kétségessé váltak egyes tradicionális stratégiai vélelmek (stabil ágazati határok, globalitás hozadéka, fenntartható versenyelöny), a tudományterület közmegegyezésen alapuló előfeltevése (nevezetesen: mi a stratégiai menedzsment tárgya és feladata) nem kérdőjeleződött meg, a világválság hatására sem. Így hát továbbra is a diszciplína keretében indokolt megjeleníteni az elméleti (és gyakorlati) fejlődést, amely fokozatos átmenetekkel volt jellemezhető az elmúlt évtizedekben. Következésképpen a tudományterületre vár a kulcsfontosságú kérdés megválaszolása: Mely környezeti faktorok hatnak a jövőben a stratégia tudatos kialakításának, illetőleg menetközbeni formálódásának folyamatára?

A racionális-normatív szemléletủ stratégiaelmélet művelői minden bizonnyal úgy tekintenek a manapság hihetetlenül gyorsan fejlődő technológiai világra, az ún. negyedik globális forradalom (Ipar 4.0) kibontakozására, mint a stratégiai menedzsment következő evolutív szakaszának egyik fő mozgató erejére. Jelenleg, az Ipar 4.0 technológiák alkalmazásának kezdeti szakaszában már megállapítást nyert, hogy a digitalizáció lényegesen módosítja a vállalati értékláncot, továbbá új értékképző munkaterületek létrehozását követeli meg (Szalavetz, 2016).

A stratégia kialakítását befolyásoló más kontextuális tényezők közül változatlanul indokolt figyelniük az elméleti szakembereknek a feltörekvő országok piacainak kihívásaira, valamint a társadalmi értékek által vezérelt, újonnan megfogalmazott elvárásokra. Kézenfekvő ugyanakkor, hogy a stratégiai menedzsment korábban kikristályosodott értékteremtési fókuszai (fogyasztói érték, tulajdonosi érték, felelős vállalati magatartás, megosztott üzleti-társadalmi érték) iránytüként szolgálhatnak a stratégiaalkotóknak. A menetközben kialakuló stratégiák teljesebb magyarázatához a vezetői döntéshozatal lélektani megközelítése nyújthat újabb támpontokat, míg az intézményalapú nézőpont megkönnyítheti az institucionális nyomás szerepének alaposabb feltárását a vállalati stratégia kialakulási folyamatában.

Mindent egybevetve, az általunk végig követett fejlődési tendenciák, a fokozatos előre lépések feltehetően érzékeltették a stratégiai menedzsment „megőrizve-továbbfejlesztve" gondolatiságát, az előző fázisok eszmei vívmányainak és praktikus újításainak alkotó felhasználását. A stratégiai menedzsment perspektíváit fontolgatva, Kornberger (2017) a stratégiaelmélet óriásainak „lábnyomában haladva” képzeli el a stratégiakutatás jövöjét, amelynek alakulása három fókusztartományból kaphat ösztönzést: stratégia és tér, stratégia és idő, stratégia és érték.

\section{Felhasznált irodalom:}

Adner, R. \& Zemsky,P.(2006). A demand-side perspective on sustainable competitive advantage. Strategic Management Journal, 215-239.
Amit, R. \& Zott, C.(2012). Creating value through business model innovation. MIT Sloan Management Review, no.3. Anderson, J.W.Jr (1989). Corporate social responsibility. New York: Quorum Books.

Angyal Á. (2001). Vállalati kormányzás. Budapest: Aula Kiadó.

Ansoff, H.I. (1965). Corporate strategy. New York: McGraw-Hill.

Balaton K. (1997). A stratégiai vezetés folyamata. In Antal-Mokos Z., Balaton K., Drótos Gy., \& Tari E. (Szerk.), Stratégia és szervezet (pp. 53-112) . Budapest: Közgazdasági és Jogi Könyvkiadó.

Balaton K.(2010). A stratégia megvalósítása és ellenőrzése. In Balaton K., Hortoványi L., Incze E., Laczkó M., Szabó Zs. R., \& Tari E. (Szerk.), Stratégiai menedzsment. Budapest: Aula Kiadó.

Barakonyi K. (2000). Stratégiai menedzsment. Budapest: Nemzeti Tankönykiadó.

Barakonyi K. (2008). Üzleti modellek. Vezetéstudomány, 5. szám.

Barry, D. \& Elmers, M.(1997). Strategy retold: toward a narrative view of strategic discourse. Academy of $\mathrm{Ma}$ nagement Review, 429-452.

Barton, D. (2011). Capitalism for the long term. Harvard Business Review, March.

Bartók I. (2007). A felelős vállalatirányítás és a vállalatkormányzás. In Könzcöl E. (Szerk.), Vállalati stratégia. Budapest: Alinea Kiadó.

Becker P., Turner A., Varsányi J., \& Virág M. (2005). Értékalapú stratégiák. Budapest: Akadémiai Kiadó.

Black, A., Wright, P., Bachman, P., \& Davies, J.(1999). In search of shareholder value. London: Price Waterhouse, U.K.

Bowman, E.H. \& Helfat, C.E. (2001). Does corporate strategy matters? Strategic Management Journal, 1-23.

Bőgel Gy. (2000). Verseny az elektronikus üzletben. Budapest: Müszaki Könyvkiadó.

Bromiley, P. \& Rau, D. (2014). Towards a practice-based view of strategy. Strategic Management Journal, 1249 - 1256.

Burgelman, R.A. (1983). A model of the interaction of strategic behavior, corporate context and the concept of strategy. Academy of Management Review, 1.

Csath M. (2015). Nemzetközi vállalatok stratégiai menedzsmentje. In Blahó A., Czakó E. \& Poór J. (Szerk.), Nemzetközi menedzsment. Budapest: Akadémiai Kiadó.

Chikán A. (2008). Vállalatgazdaságtan. Budapest: Aula Kiadó.

Child, J. \& Faulkner, D. (1998). Strategies of cooperation. Oxford: Oxford University Press.

Copeland,T., Coller, T., \& Murrin, J. (1994). Valuation: measuring and managing the value of companies. New York: John Wiley and Sons.

Crossland, C. \& Hambrick, D.C. (2007). How national systems differ in their constraints on corporate executives. Strategic Management Journal, 767-789.

Czakó E.(2007). A vállalati stratégia és az érintettek. In Könczöl E. (Szerk.), A vállalati stratégia. Budapest: Alinea Kiadó. 
D’ Aveni, R.A. (1994). Hypercompetition: managing the dynamics of strtategic maneuvering. New York: Free Press.

D’ Aveni, R.A., Dagnino, G.B., \& Smith, K.G. (2010). The age of temporary advantage. Strategic Management Journal, special issue, 1371-1385.

Dobák M. \& Tari E. (2015). Nemzetközi konszernek és holdingok irányításáról. In Blahó A., Czakó E., \& Poór J. (Szerk.), Nemzetközi menedzsment. Budapest: Akadémiai Kiadó.

Dyer, J.H. (2000). Collaborative advantage. Oxford: Oxford University Press.

EBF (European Business Forum) (2001). Does strategy really matter anymore? issue 8 ,winter.

Eisenhardt, K.M. \& Martin, J. (2000). Dynamic capabilities - what they are? Strategic Management Journal, $1105-1121$.

Evans, P. \& Wurster, T. (2000). Blown to bits - how the new economics of information transform strategy. Boston: Harvard Business School Press.

Farkas F. (2005). Változás-menedzsment. Budapest: Akadémiai Kiadó.

Felsmann B. (2016). Do institutions matter in business strategy? Vezetéstudomány, 5. szám.

Freeman, R.E. (1984). Strategic management: a stakeholder approach. Boston: Pitman.

Freeman, R.E. \& McVea, J. (2005). A stakeholder approach to strategic management. In Hitt, M.A., Freeman, R.E., \& Harrison, J.S. (Eds.), The Blackwell handbook of strategic management. Malden: Blackwell Publishing.

Galbraith, J.R. \& Kazanjian, R.K. (1986). Strategy implementation: structure, systems and process. St. Paul: West Publishing.

Gavetti, G. (2010). Toward a behavioral theory of strategy. Organization Science, no.1.

Ghemawat, P. (2010). Finding your strategy in the new landscape. Harvard Business Review, March.

Grant, R.M. (1996). Towards a knowledge-based theory of the firm. Strategic Management Journal,109-122.

Grant, R.M. \& Visconti, M. (2006). The strategic background to corporate accounting scandals. Long Range Planning, no.8.

Grove, A.S. (1997). Only the paranoid survive. New York: Harper Collins Publishers.

Guerras-Martin, L.A., Madhok, A., \& Montoro-Sanches, A. (2014). The evolution of strategic management research: recent trends and current directions. BRQ Business Research Quarterly, no2.

Hermann, P. (2005). Evolution of strategic management, the need for new dominant design. International Journal of Management Reviews, issue 2.

Hong, H-J. \& Doz,Y. (2013). L'Oréal masters multiculturalism. Harvard Business Review, June.

Hrebiniak, L.G. \& Joyce, W.F. (1984). Implementing strategy. New York: Macmillan.

Hrebiniak, L.G. \& Joyce, W.F. (2005). Implementing strategy: an appraisal and agenda for future research. In Hitt, M.A., Freeman, R.E., \& Harrison, J.S.(Eds.), The Blackwell handbook of strategic management. Malden: Blackwell.
Huff, A.S. (Ed.)(1990). Mapping strategic thought. New York: John Wiley and Sons.

Imre T. (2017). Stratégiai menedzsment a vállalati gyakorlatban. Budapest: Magánkiadás.

Ingram, P. \& Silverman, B. (2002). Introduction. In Ingram, P. \& Silverman, B. (Eds.), The new institutionalism in strategic management. Amsterdam: Elsevier.

Ireland, R.D., Hitt, M.A., \& Sirmon, D.G. (2003). A model of strategic entrepreneurship: the construct and its dimensions. Journal of Management, 963-989.

Jacobides, M.G. \& MacDuffie, J.P. (2013). How to drive value your way. Harvard Business Review, July-August.

Jacobson, R. (1992). The ,austrian” school of strategy. Academy of Management Review, no.4.

Jarzabkowski, P. (2005). Strategy as practice: an activitybased approach. London: Sage.

Kahneman, D., Slovic,P. \& Tversky, A. (1982). Judgement under uncertainty: heuristics and biases. Cambridge: Cambridge University Press.

Kaplan, R.S. \& Norton, D.P. (1996). The Balanced Scorecard. Boston: Harvard Business School Press.

Kaplan, R.S. \& Norton, D.P. (2004). Strategy maps. Boston: Harvard Business School Publishing.

Kaplan, R.S. \& Norton, D.P. (2005). The office of strategy management. Harvard Business Review, October.

Kim,W.C. \& Mauborgne, R. (2005). Value innovation: a leap into the blue ocean. Journal of Business Strategy, no.4.

Kim, W.C. \& Mauborgne, R. (2017). Blue ocean shift: beyond competing. New York: Hachette Books.

Kirzner, I.M. (1979). Perception, opportunity and profit. Chicago: University of Chicago Press.

Kocsis É. \& Szabó K. (2000). A posztmodern vállalat. Budapest: Oktatási Minisztérium.

Kornberger, M. (2017). Stepping on the toes of giants,or how to review the future of strategy research. In Czarniawska, B. (Ed.), A research agenda for management and organization studies. Cheltenham: Edward Elgar.

Könczöl E. (2007). Stratégiai megközelítések, stratégia és a vállalati érték. In Könczöl E. (Szerk.), Vállalati stratégia. Budapest: Alinea Kiadó.

Learned, E.P., Christensen, C.R., Andrews, K.R., \& Guth,W.D. (1965). Business policy: text and cases. Homewood: Richard D.Irwin.

Lovallo,D. \& Kahneman, D. (2003). Delusions of success:how optimism undermines executives' decisions. Harvard Business Review, July.

Lovallo, D. \& Sibony, O. (2010). The case for behavioral strategy. McKinsey Quarterly, March.

Lynch, R. (2006). Corporate strategy. London: Prentice Hall-Financial Times.

Madhok, A. \& Marques, R. (2014). Towards an action-based perspective on firm competitiveness. BRQ Business Research Quaterly, no.2.

Marosán Gy. (2006). A 21. század stratégiai menedzsmentje. Budapest: Müszaki Könykiadó.

Martin, R. (2010). The age of customer capitalism. Harvard Business Review, January-February. 
McGrath, R.G. \& MacMillan, I. (2000). The entrepreneurial mindset. Boston: Harvard Business School Press.

McIntyre, D.P. \& Srinivasan, A. (2017). Networks, platforms, and strategy. Strategic Management Journal, 141-160.

Mellewigt, T., Bruhs, S.M., \& Keller,A. (2017). Behavioral alliance strategy. In Mesquita, L.F., Ragazzino,R., \& Reurer, J.J. (Eds.), Collaborative strategy. Cheltenham: Edward Elgar.

Mészáros T. (2002). A stratégia jövője - a jövő stratégiája. Budapest: Aula Kiadó.

Mészáros T. (2015). Van-e élet a stratégiai menedzsment után? In Bakacsi Gy. \& Balaton K. (Szerk.), Vezetés és szervezet társadalmi kontextusban.Tanulmányok Dobák Miklós 60. születésnapja tiszteletére. Budapest: Akadémiai Kiadó.

Miller, D. (1979). Strategy, structure, and environment. Journal of Management Studies, 294-316.

Mintzberg, H. (1987). Crafting strategy. Harvard Business Review, April.

Mintzberg, H., Ahlstrand, B., \& Lampel, J. (1998). Strategy safari. New York: Free Press.

Moore, G.A. (2002). Crossing the chasm. New York: Harper Business.

Móricz P. (2007). Üzleti modellezés és az internetes üzleti modellek. Vezetéstudomány, 4. szám.

Nag, R., Hambrick, D.C., \& Chen, M-J. (2007). What is strategic management? Strategic Management Journal, 935-955.

North, D. (1990). Institutions, institutional change, and economic performance. New York: Norton.

Oliver, C. (1991). Strategic responses to institutional processes. Academy of Management Review, 145-179.

O'Reilly, C.A. \& Tushman, M.L. (2008). Ambidexterity as a dynamic capability:resolving the innovator's dilemma. Research in Organizational Behavior, 185-206.

Pearce, J.A. \& David, F.R. (1987). Corporate mission statements:the bottom line. Academy of Management Executive, May.

Peng, M.W., Sun, S.L., Pinkham, B., \& Chen,H. (2009). The institution-based view as a third leg for a strategy tripod. Academy of Management Perspectives, no.3.

Polowczyk, J. (2012). Strategic management at the beginning of the XXI. century: the impact of crisis turbulences. Poznan University of Ecomnomics Review, no.3.

Porter, M.E. (1980). Competitive strategy: techniques for analyzing industries and competitors. New York: Free Press.

Porter, M.E. (1985). Competitive advantage:creating and sustaining superior performance. New York: Free Press.

Porter, M.E. (2008). The five competitive forces that shape strategy. Harvard Business Review, January.

Porter, M.E. \& Kramer, M. (2011). Creating shared value. Harvard Business Review, January-February.

Porter, M.E. \& Heppelmann, J.E. (2014). How smart, connected products are tansforming the competition. Harvard Business Review, November.

Powell, T.C., Lovallo, D., \& Fox, C.R. (2011). Behavioral strategy. Strategic Management Journal, 1369-1386.

Quinn, J.B. (1980). Strategies for change: logical incrementalism. Homewood: Richard D.Irwin.

Rappaport, A. (1998). Creating shareholder value. New York: Free Press.
Rappaport, A. (2006). 10 ways to create shareholder value. Harvard Business Review, September.

Salamonné Huszty A. (2002). Jövőkép-és stratégiaalkotás. Budapest: Kossuth Kiadó.

Schwenk, C. (1988). The cognitive perspective in strategic decision-making. Journal of Management Studies, 41-56.

Scott, W.R. (1995). Institutions and organizations. Thousand Oaks: Sage.

Sirmon, D.G., Hitt, M.A., Ireland, R.D., \& Gilbert, B.A. (2011). Resource orchestration to create competitive advantage. Journal of Management, 1390-1412.

Stevenson, H.H. \& Gumpert, D.E. (1985). The heart of entrepreneurship. Harvard Business Review, March-April.

Stewart, G.B. (2013). Best-Practice EVA. New York: John Wiley and Sons.

Szabó K. \& Kocsis É.(2001). Digitális paradicsom vagy falanszter?(a személyes tömegtermelés). Budapest: Aula Kiadó.

Szalavetz A. (2016). Az ipar 4.0 technológiák gazdasági hatásai. Külgazdaság, 7-8.szám.

Szintay I. (2001). Stratégiai menedzsment. Miskolc: Bíbor Kiadó.

Tapscott, D. (2001). Rethinking strategy in a networked word. Strategy+Business, fall.

Tari E. (1998). Stratégiai szövetségek az üzleti világban. Budapest: Közgazdasági és Jogi Könyvkiadó.

Tari E. (2005): Egy szervezeti összeolvadás (beolvasztás?) esete: a német-amerikai Daimler Chrysler. In Bakacsi Gy., Balaton K., \& Dobák M. (Szerk.), Változás és vezetés. Budapest: Aula Kiadó.

Tari E. (2007). A stratégiai gondolkodás fejlödése. In Balaton K. \& Tari E. (Szerk.). Stratégiai és üzleti tervezés. Budapest: Aula Kiadó.

Tari E. (2015). Adalékok a stratégiai menedzsment fejlődéstörténetéhez. In Bakacsi Gy. \& Balaton K. (Szerk.). Vezetés és szervezet társadalmi kontextusban. Tanulmányok Dobák Miklós 60. születésnapja tiszteletére. Budapest: Akadémiai Kiadó.

Taródy D. (2016). Organizational ambidexterity as a new research paradigm in strategic management. Vezetéstudomány, 5.szám.

Thompson, A.A.Jr \& Strickland, A.J. (1992). Strategic management. Concepts and cases. Homewood: Richard D. Irwin.

Tricker, B. (2015). Corporate governance. Oxford: Oxford University Press.

Van Alstyne, M.W., Parker, G.G., \& Choudary, S.P. (2016). Pipelines, platforms and the new rules of strategy. Harvard Business Review, April.

Wang, C.L. \& Ahmed, P.K. (2007). Dynamic capabilites: a review and research agenda. International Journal of Management Reviews, 31-51.

Whittington, R., Cailluet, L., \& Yakis-Douglas, B. (2011). Open strategy: evolution of a precarious profession. British Journal of Management, 531-544.

Wiggins, R.R. \& Ruefli, T.W. (2002). Sustained competitive advantage: temporal dynamics and the incidence and persistence of superior economic performance. Organization Science, no.1. 